\title{
Relevance of Candidatus Nitrotoga for nitrite oxidation in technical nitrogen removal systems
}

\author{
Eva Spieck $^{1}$ (D) $\cdot$ Simone Wegen ${ }^{1} \cdot$ Sabine Keuter $^{1}$
}

Received: 26 March 2021 / Revised: 29 July 2021 / Accepted: 31 July 2021 / Published online: 11 September 2021

(c) The Author(s) 2021

\begin{abstract}
Many biotechnological applications deal with nitrification, one of the main steps of the global nitrogen cycle. The biological oxidation of ammonia to nitrite and further to nitrate is critical to avoid environmental damage and its functioning has to be retained even under adverse conditions. Bacteria performing the second reaction, oxidation of nitrite to nitrate, are fastidious microorganisms that are highly sensitive against disturbances. One important finding with relevance for nitrogen removal systems was the discovery of the mainly cold-adapted Cand. Nitrotoga, whose activity seems to be essential for the recovery of nitrite oxidation in wastewater treatment plants at low temperatures, e.g., during cold seasons. Several new strains of this genus have been recently described and ecophysiologically characterized including genome analyses. With increasing diversity, also mesophilic Cand. Nitrotoga representatives have been detected in activated sludge. This review summarizes the natural distribution and driving forces defining niche separation in artificial nitrification systems. Further critical aspects for the competition with Nitrospira and Nitrobacter are discussed. Knowledge about the physiological capacities and limits of $\mathrm{Cand}$. Nitrotoga can help to define physico-chemical parameters for example in reactor systems that need to be run at low temperatures.
\end{abstract}

Key points

- Characterization of the psychrotolerant nitrite oxidizer Cand. Nitrotoga

- Comparison of the physiological features of Cand. Nitrotoga with those of other NOB

- Identification of beneficial environmental/operational parameters for proliferation

Keywords Nitrification $\cdot$ Nitrite oxidizing bacteria $\cdot$ Cand. Nitrotoga $\cdot$ Environmental distribution $\cdot$ Selective factors

\section{Introduction}

Nitrification is the biological oxidation of ammonia to nitrate in two steps, performed by highly specialized ammonia oxidizing bacteria/archaea (AOB/AOA) and nitrite oxidizing bacteria (NOB). This process is of environmental importance to avoid accumulation of harmful ammonia and nitrite, which can result in human and aquatic animal health risk (Camargo and Alonso 2006). Furthermore, the endproduct of nitrification-nitrate-causes eutrophication of effluent-receiving waters from wastewater treatment plants (WWTPs), but can be reduced to nitrous oxide and molecular nitrogen by nitrifying and heterotrophic denitrifying

Eva Spieck

eva.spieck@uni-hamburg.de

1 Department of Microbiology and Biotechnology, Universität Hamburg, Hamburg, Germany bacteria. Therefore, nitrification is essential to remediate excessive $\mathrm{N}$-nutrients from sewage and contributes to global nitrous oxide emissions.

In engineered systems, ammonia oxidation, the first step of nitrification, is mainly performed by Betaproteobacteria of the genus Nitrosomonas (Koops and PommereningRöser 2001). In contrast, NOB, which consume the product of ammonia oxidation, are a very heterogenous group and their members are spread over the phylogenetic tree (Fig. 1). Nitrospira is considered as key NOB in municipal and industrial WWTPs (Daims et al. 2006; Wu et al. 2019) with a high phylogenetical and metabolic diversity (Pester et al. 2014; Koch et al. 2015). The awareness of this NOB increased once again with the discovery of comammox Nitrospira, combining ammonia and nitrite oxidation in a single cell (Daims et al. 2015; Van Kessel et al. 2015). Although research on nitrite oxidation has a long tradition in microbiology, an impressive taxonomic and physiological 


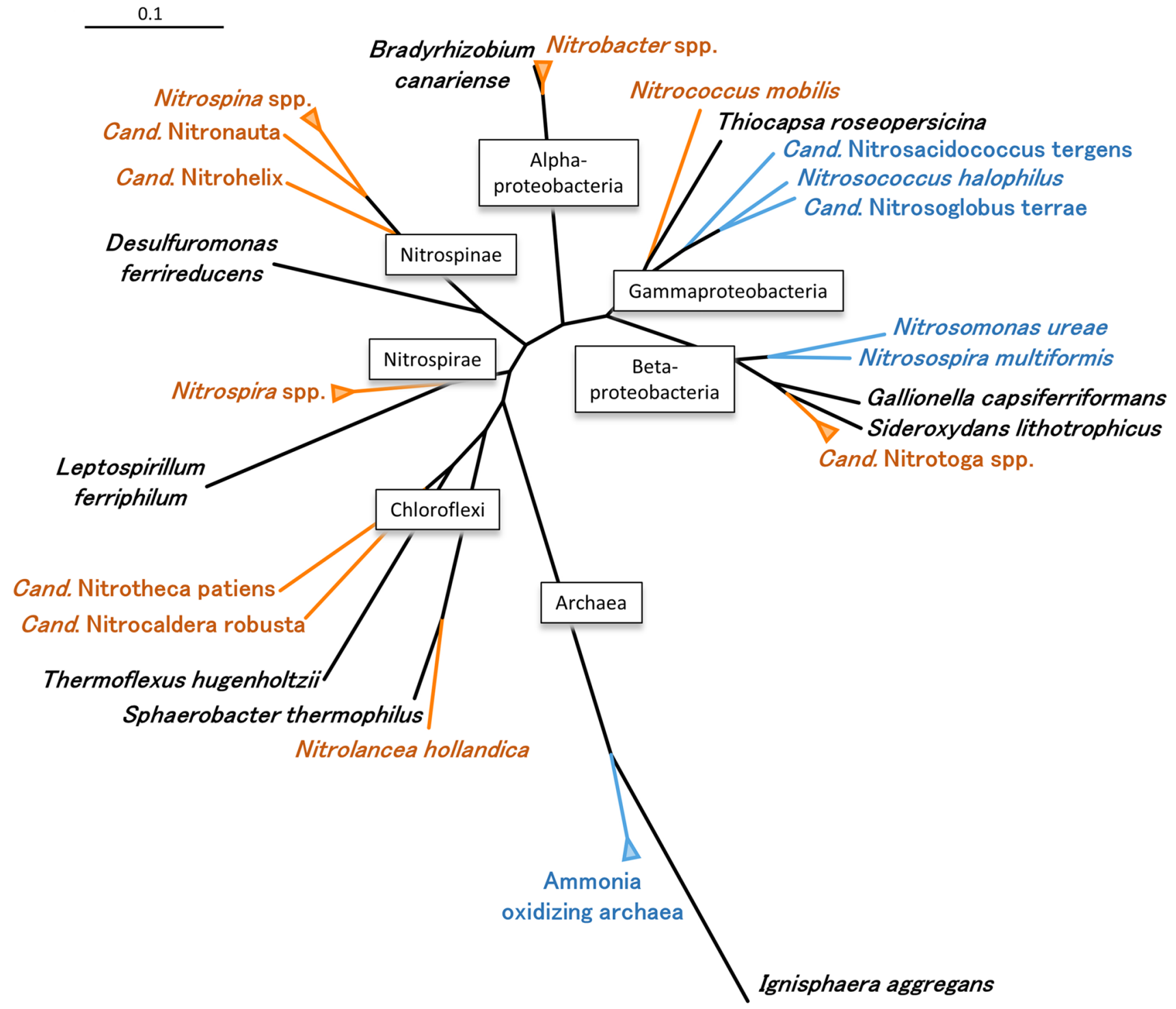

Fig. 1 Phylogenetic tree (NJ) based on 16S rRNA genes showing the relationships of known genera of nitrite oxidizing bacteria (in red) in their respective phylum/class between each other, with closely related

diversity was uncovered only within the last few years (Koch et al. 2014, 2015; Daims et al. 2016; Spieck et al. 2020a, b; Mueller et al. 2021).

Only a few years ago, the nitrite-oxidizing genus Cand. Nitrotoga was discovered among nitrifiers in permafrostaffected soil from Samoylov Island in the Lena Delta (Alawi et al. 2007). Diverse microbial communities are able to survive the harsh environmental conditions and Cand. Nitrotoga coexists with Nitrospira and Nitrobacter in this N-limited ecosystem (Wagner et al. 2001; Sanders et al. 2019). No representative of the latter two NOB was cultivated at low temperatures and solely Cand. Nitrotoga arctica could be enriched when incubation temperatures between 4 and $17^{\circ} \mathrm{C}$ were used, which are lower than the in situ maximum non-nitrifying bacteria (in black) and ammonia oxidzing bacteria/ archaea (in blue). The scalebar indicates 0.1 estimated nucleotide substitutions per site

temperature of Siberian soil during summer. Cells of Cand. Nitrotoga are irregularly shaped short rods or cocci, which are characterized by a distinct ultrastructure with an unusually wide periplasmic space, hence the name "toga" (Alawi et al. 2007; Fig. 2a). Like other NOB, they live in microcolonies, but the biofilm formation is less pronounced than in Nitrospira or Nitrobacter (Fig. 2b). The individuals are connected by a loose structure of extracellular polymeric substances (EPS) in small aggregates, which can occur in close vicinity to AOB (Lücker et al. 2015). Phylogenetically, the cold-adapted NOB belongs to the Betaproteobacteria-like ammonia oxidizing bacteria (Nitrosomonas, Nitrosospira) (Fig. 1).

Since the description of $N$. arctica in 2007, an increasing number of Cand. Nitrotoga representatives have been 
Fig. 2 Electron micrographs of ultrathin sections of Cand. Nitrotoga cells revealing the characteristic ultrastructure. a Cand. N. arctica in division, with the extraordinary wide periplasmic space of particulate nature. b Microcolony of Cand. Nitrotoga with cells surrounded by thin layers of EPS. $\mathrm{cm}=$ cytoplasmic membrane, $\mathrm{p}=$ periplasm, om $=$ outer $\mathrm{mem}-$ brane, $c y=$ cytoplasm
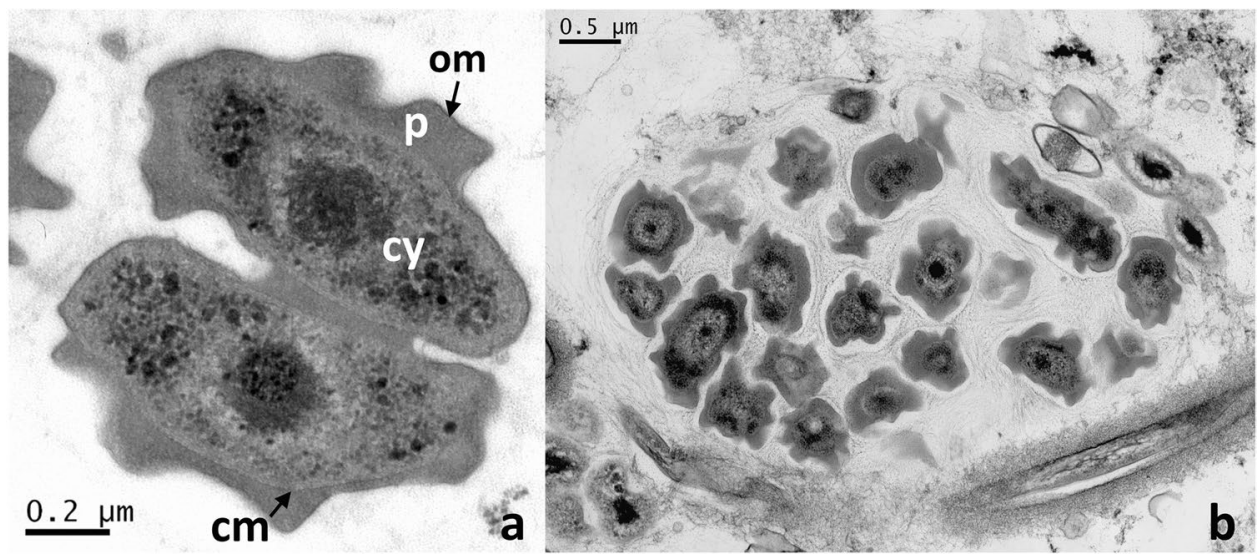

detected in natural as well as engineered ecosystems. Successful enrichments were initiated with samples from permafrost soil, activated sludge, freshwater and marine biofilters, rivers, coastal sediment, and the terrestrial subsurface (Alawi et al. 2007, 2009; Boddicker and Mosier 2018; Hüpeden et al. 2016; Ishii et al. 2017; Keuter et al. 2017; Kitzinger et al. 2018; Wegen et al. 2019).

Typical for most NOB, growth of Cand. Nitrotoga with nitrite as substrate is slow with generation times of $44-54 \mathrm{~h}$ (Nowka et al. 2015a; Ishii et al. 2017). To date, there are only two pure cultures available (Kitzinger et al. 2018; Ishii et al. 2020), and as described for Nitrospira (Nowka et al. 2015b), isolation is time-intensive and requires a combination of several methods, mainly to eliminate accompanying heterotrophic bacteria that adhere to and use organic material excreted by the NOB. Furthermore, growth of the NOB might benefit or even require the exchange of metabolites or other cofactors like ammonium (Wegen et al. 2019; Ishii et al. 2020) in coculture with heterotrophs. Cand. Nitrotoga could be frozen by a special cryopreservation method (Vekeman et al. 2013), but reactivation of stored cultures is less successful than for other NOB and deposition in bacterial culture collections was not possible due to the extensive need of manpower. As a consequence, no strain has been validly described and Nitrotoga is still a Candidatus taxon (Oren et al. 2020).

Notably, since Cand. Nitrotoga was not classified by the RDP database (Navada et al. 2020a), it can be-and possibly often was-easily overlooked in 16S rRNA-based analyses. Therefore, to target these NOB in studies of N-removal systems, appropriate methods should be used.

\section{Occurrence in natural habitats}

The environmental distribution of Cand. Nitrotoga-related $16 \mathrm{~S}$ rRNA gene sequences confirmed that many of these NOB are associated with low temperatures in extreme environments. However, closely related 16S rRNA gene sequences were not restricted to cold climates, but were found to be globally distributed from the tropics to the poles over a wide range of temperatures. A search against sequences in the NCBI Sequence Read Archive found that sequences of these NOB were detected mainly in samples from soils, wastewater, sediments, and freshwater, and in some of the samples, a temperature of about $30^{\circ} \mathrm{C}$ was measured (Boddicker and Mosier 2018).

Polar regions are a typical habitat for Cand. Nitrotoga (Alawi et al. 2007; Achberger et al. 2016; Kohler et al. 2020) and, for example, in the subglacial Lake Whillans in the West Antarctic, it was among the most abundant bacteria and the only NOB (Christner et al. 2014). In this deep cold freshwater habitat, which is covered by an $800-\mathrm{m}$ ice sheet, nitrification is one of the drivers for primary production to sustain microbial life. Accordingly, Cand. Nitrotoga was also found in high-elevated (peri)glacial soils and they were likely involved in nitrification in soils exposed to extreme freeze-thaw cycles (Pradhan et al. 2010; Schmidt et al. 2009). Strong temperature fluctuations were also measured in annual cycles of a seasonally ice-covered river in Canada. Here, the abundance of Cand. Nitrotoga increased in the late winter season in correlation with a rise in the nitrogen concentration (Cruaud et al. 2020). In a subalpine peatland in China, Cand. Nitrotoga was identified as one of a few keystone species of the bacterial communities (Tian et al. 2020) and it was the most abundant nitrifier in cryoconite granules on glacier surfaces in China (Segawa et al. 2020).

Further natural habitats for Cand. Nitrotoga are temperate freshwater, groundwater, or $\mathrm{CO}_{2}$-rich mineral water (Krauze et al. 2017). High abundances were found in an ice-covered Canadian lake (Fournier et al. 2021) and in the Laurentian great lakes (Paver et al. 2020). Four different Cand. Nitrotoga cultures were enriched from urban- or agriculturally impacted rivers in CO, USA (Boddicker and Mosier 2018), and it was also detected in the tidal reach of the Yangtze river (Fan et al. 2016). Additionally, different kinds of filter 
systems used for the production of drinking water provided a suitable surface to enrich high cell numbers of Cand. Nitrotoga reaching about $20 \%$ of the $16 \mathrm{~S}$ rRNA gene sequences (Kaarela et al. 2015; Cai et al. 2016; Albers et al. 2018; White et al. 2012; Table S1). In drinking water distribution systems, Cand. Nitrotoga coexisted together with Nitrospira and Nitrobacter and its abundance increased when the water was disinfected with chloramine (Waak et al. 2019).

Additionally, Cand. Nitrotoga is a main NOB involved in primary production driven by geochemical processes in caves and subsurface soils. Its activity was revealed in the sulfur- and ammonium-based chemolithotrophy in the Movile cave, Romania (Chen et al. 2009), and a strain was enriched from samples of the Äspö Hard Rock Laboratory, Sweden (Keuter et al. in preparation). It became obvious that Cand. Nitrotoga often occurs in Fe-based microbial ecosystems, e.g., in a groundwater seep (Roden et al. 2012), the Sitarjevec Mine, Slovenia (Toplak et al. 2021), the mentioned Äspö Hard Rock Laboratory (Ionescu et al. 2015) or Fe-rich paddy soil (Naruse et al. 2019). Interestingly, the next related taxonomically described bacteria are the iron oxidizers Gallionella ferruginea and Sideroxydans lithotrophicus. Comparative genomics of Cand. Nitrotoga from river sediment and water column samples revealed an array of genes for iron acquisition, which may offer a competitive advantage in iron-limited environments, but siderophores were not present (Boddicker and Mosier 2018). As iron-sulfur centers are involved in the transformation of nitrite to nitrate (Meincke et al. 1992), the availability of this element is crucial to maintain the energy delivering reaction active.

\section{Cand. Nitrotoga in engineered ecosystems}

\section{Wastewater treatment plants}

The occurrence of Cand. Nitrotoga is not restricted to environmental habitats with more or less low dissolved inorganic nitrogen concentrations, but it also proliferates in nutrient-rich wastewaters and activated sludge. This became apparent with cultivation of a potential new player in municipal $\mathrm{N}$-removal systems. Incubations at $10-17^{\circ} \mathrm{C}$ of activated sludge (AS) from a WWTP in Hamburg resulted in the selective enrichment of the second cultivated Cand. Nitrotoga representative with preference for low temperatures (Alawi et al. 2009). Cand. Nitrotoga was since then detected in many full-scale municipal WWTPs and laboratory or pilot-scale bioreactors operated with AS, but its occurrence seemed to be dependent on the geographic location (Table S1) with a clearly different distribution than Nitrospira (Cohen et al. 2019). Seasonal high abundances were observed in WWTPs located in cold or moderate climates (see below).
In the WWTP in Hamburg, the cell numbers of Cand. Nitrotoga were rather low compared to Nitrospira (Fig. 3); however, labeled fatty acid profiles suggested that it was well metabolically active (Kruse et al. 2013a).

So far, Cand. Nitrotoga is the only known psychrotolerant NOB (Moyer et al. 2017) and the capability to oxidize nitrite also at temperatures too low for other cultured NOB broadens biotechnological applications in order to save energy for heating processes. Wastewaters in temperate climate zones are rarely above $20{ }^{\circ} \mathrm{C}$ (Dempsey 2017) and frequently undergo seasonal nitrification failure in winter, because a reduced water temperature below $13{ }^{\circ} \mathrm{C}$ reduces activity of most nitrifiers (Johnston et al. 2019).

\section{Recirculating aquaculture systems}

Comparable to activated sludge, nitrification in biofilters of recirculating aquaculture systems (RAS) is mostly dominated by Nitrospira (Foesel et al. 2008; Keuter et al. 2011; Kruse et al. 2013b; Hüpeden et al. 2020) but especially in the Northern Hemisphere reports about occurrences as well as functional dominance of Cand. Nitrotoga are increasing. Cand. Nitrotoga occurred in high abundances $(>40 \%)$ in cold freshwater and brackish RAS (8per mill salt) in Norway (Navada et al. 2019, 2020a). It was also the main NOB in a cold freshwater RAS in

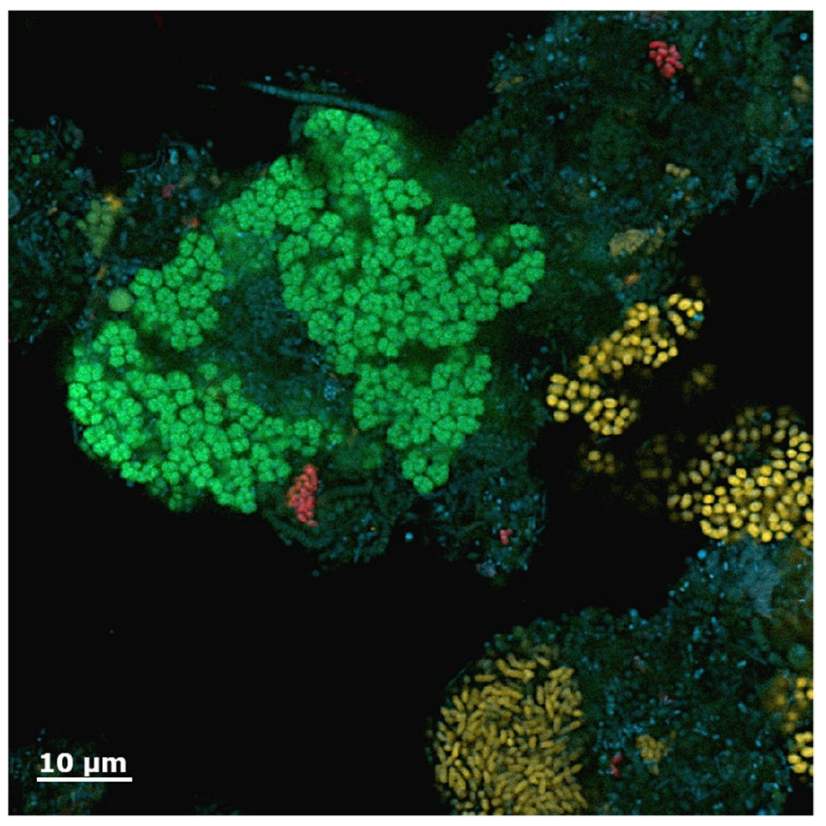

Fig. 3 Microcolonies of Cand. Nitrotoga in activated sludge of the WWTP Hamburg-Dradenau, sampled in early spring. Nitrotoga cells were labeled by fluorescence in situ hybridization (FISH) with the oligonucleotide probe Ntg122 (Lücker et al. 2015), and appear as pleomorphic short rods in red. Nitrospira (green) was labeled with probes Nsp662 and Nsp712, Nitrosomonas (yellow) with probes Nm190 and Nm1225. All bacteria were staind with DAPI (blue). The image was taken with a Zeiss LSM 800 
Northern Germany, which was operated at a slightly acidic $\mathrm{pH}$ of 6.8 (Hüpeden et al. 2016). Furthermore, Nitrospira and/or Cand. Nitrotoga were the most abundant NOB in freshwater as well as brackish RAS bioreactors in Finland (Pulkkinen 2020). In the freshwater system, their distribution seemed dependent on the type of bioreactor (probably with different oxygenation of the biofilms, see below), because Nitrospira (as NOB and comammox) dominated the fixed bed reactor, whereas Cand. Nitrotoga was most abundant in the moving bed reactor. From the biofilters of a marine RAS running with North Sea water, the first marine cultures of this NOB could be enriched and further characterized (Keuter et al. in preparation). Its role in nitrification in this RAS however seemed minor. With the relatively high occurrence of Cand. Nitrotoga in non-saline WWTPs, it is rather surprising that the cold-adapted NOB was not found in more freshwater aquaculture systems. Its presence in marine systems however seems less likely, given that in general, $16 \mathrm{~S}$ rRNA gene sequences of Cand. Nitrotoga in marine settings were rarely detected (Boddicker and Mosier 2018).

\section{Lessons learned from Cand. Nitrotoga cultures}

\section{Temperature adaptation}

Low temperature is a main selective factor responsible for the dominance of Cand. Nitrotoga (Alawi et al. 2009; Lücker et al. 2015) and nearly all cultures grow well at $4{ }^{\circ} \mathrm{C}$, in contrast to Nitrospira and Nitrobacter (Ushiki et al. 2013; Nowka et al. 2015b; Fig. 4). Cand. Nitrotoga arctica grows best between 10 and $17^{\circ} \mathrm{C}$ and for most other strains of these NOB temperature optima between 17 and $22{ }^{\circ} \mathrm{C}$ were determined (Alawi et al. 2007; Hüpeden et al. 2016; Wegen et al. 2019; Ishii et al. 2017, 2020; Keuter et al. in preparation). An exception is the isolate Cand. Nitrotoga fabula from a WWTP in Austria, which is not adapted to low temperatures and only poorly grew $<20{ }^{\circ} \mathrm{C}$ (optimum at 24-28 ${ }^{\circ} \mathrm{C}$ ) (Kitzinger et al. 2018). Interestingly, the isolate with a bean-like shape revealed a different morphology than other cultivated Cand. Nitrotoga strains, and the 16S rRNA gene sequence forms a sublineage in the phylogenetic tree. In accordance, the ANI (average nucleotide identity) values between Cand. Nitrotoga fabula and other cultures of this genus are rather low (Keuter et al. in preparation).

\section{Influence of the substrate concentration}

At first, the new genus of NOB seemed to be already inhibited by relatively low substrate concentrations, especially in comparison to Nitrobacter (Alawi et al. 2007; Bartosch et al. 1999). Meanwhile, new additional data from cultivated strains are available and higher tolerance levels were found

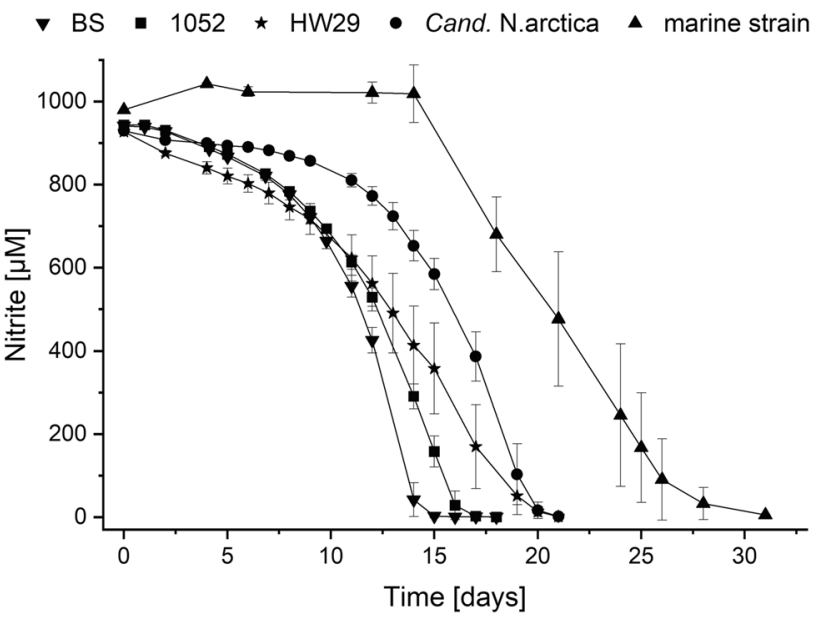

Fig. 4 Nitrite oxidation of five Cand. Nitrotoga strains at an incubation temperature of $4{ }^{\circ} \mathrm{C}$. The consumption of about $1 \mathrm{mM}$ nitrite took between 15 (strain BS) and 30 (marine strain) days. Values are means \pm standard deviations (error bars) for three biological replicates. Cand. N. arctica and Cand. Nitrotoga sp. 1052 originate from permafrost soil (Alawi et al. 2007; Keuter et al. in preparation), strain BS from activated sludge (Wegen et al. 2019), strain HW29, and the marine strain from aquaculture biofilters (Hüpeden et al. 2016; Keuter et al. 2017)

in correlation with the findings of Lücker et al. (2015). Three Cand. Nitrotoga strains (from marine aquaculture, coastal sediments, and Cand. Nitrotoga fabula) were resistant to $>20 \mathrm{mM}$, whereas cultures obtained from permafrost soils were nitrite-sensitive and did not grow in $>4 \mathrm{mM}$ (Ishii et al. 2020; Kitzinger et al. 2018; Keuter et al. in preparation).

\section{Biochemistry}

The key enzyme of nitrite oxidation, the nitrite oxidoreductase (NXR), is a molybdopterin-binding enzyme within the DMSO reductase type II family (Meincke et al. 1992; Lücker et al. 2010), which occurs in two different forms. The Nitrobactertype NXR is bound to the inner side of the cytoplasmic and intracytoplasmic membranes (Spieck et al. 1998) and is closely related to nitrate reductases (NarG) of denitrifying bacteria (Kirstein and Bock 1993). The Nitrospira-type NXR faces the periplamic space and is related to the NXR in anaerobic ammonium-oxidizing Brocardiaceae (Lücker et al. 2010). Mostly, the substrate affinity of NOB with a periplasmic NXR (Nitrospira, Nitrospina) is higher in comparison to NOB with a cytoplasmic localization (Nitrobacter, Nitrococcus, Nitrolancea), and the inhibition threshold for nitrite is lower (Off et al. 2010; Nowka et al. 2015a).

Cand. Nitrotoga contains a new type of periplasmic nitrite oxidoreductase, which is phylogenetically distinct to the key enzymes with the same localization (Kitzinger et al. 2018; Boddicker and Mosier 2018) and $\mathrm{K}_{\mathrm{m}}$ values for nitrite (measured with total cells) revealed values between 
those of Nitrospira and Nitrobacter. In detail, the $\mathrm{K}_{\mathrm{m}}$ was in a moderate range of $25-89 \mu \mathrm{M}$ nitrite for the different species of Cand. Nitrotoga (Ishii et al. 2017; Kitzinger et al. 2018; Nowka et al. 2015a; Wegen et al. 2019) and therefore presents rather a $K$-strategist (like Nitrospira) than an $r$-strategist (like Nitrobacter). The maximum specific activity of Cand. Nitrotoga $\left(\mathrm{V}_{\max }=19-52 \mu \mathrm{mol}\right.$ nitrite/mg protein per hour) lies in the Nitrospira range, but is clearly lower than the oxidation rates of Nitrobacter (Kitzinger et al. 2018; Nowka et al. 2015a; Wegen et al. 2019).

\section{Carbon fixation and adaptation to high DO}

With regard to $\mathrm{CO}_{2}$ fixation, Cand. Nitrotoga differs from the other NOB with periplasmic NXR by using the CalvinBenson-Bassham (CBB) cycle like Nitrobacter, Nitrococcus, and nitrite-oxidizing Chloroflexi (Boddicker and Mosier 2018; Kitzinger et al. 2018; Sorokin et al. 2012; Spieck et al. 2020b). This cycle requires a higher energy input than the reductive TCA cycle used by Nitrospira and Nitrospina (Berg 2011). Another concern is that some enzymes of the rTCA cycle are oxygen-sensitive, and therefore, this cycle is widespread among anaerobic or microaerobic bacteria. Its functioning in aerobic bacteria like Nitrospira requires enzymatic adaptations (Lücker et al. 2010). In contrast, the enzymes of the CBB cycle have a high robustness to molecular oxygen (Berg 2011), which can effect a competitive advantage over Nitrospira in high-oxygen habitats, as was shown for Nitrobacter (Downing and Nerenberg 2008; Huang et al. 2010). Nevertheless, in accordance with their microaerophilic ancestors, Cand. Nitrotoga as well as Nitrospira can cope with low DO since at least some species have a high affinity cytochrome $\mathrm{cbb}_{3}$ oxidase (Bayer et al. 2021; Boddicker and Mosier 2018; Kitzinger et al. 2018).

Apart from the enzymatic equipment, it is speculated that lipid patterns are involved in protection from high DO like regulation by hopanoid abundance in some NOB, but not in Cand. Nitrotoga (Elling et al. submitted).

\section{Low $\mathrm{pH}$ values}

Two strains of Cand. Nitrotoga, N. arctica and HW29, were highly enriched from slightly acidic environments and had low pH optima of 6.4 and 6.8 , respectively. Sustaining the reduced $\mathrm{pH}$ during cultivation, Nitrospira was finally eliminated from Cand. Nitrotoga (Hüpeden et al. 2016; Wegen 2017). It seemed therefore that low $\mathrm{pH}$ was another selective factor for the competition between Cand. Nitrotoga and Nitrospira. However, tests for $\mathrm{pH}$ preferences of other Cand. Nitrotoga cultures showed that the $\mathrm{pH}$ optimum lies in the neutral to slightly alkaline range as typical for nearly all NOB (Ishii et al. 2020; Kitzinger et al. 2018). Further examples from bioreactors revealed that $\mathrm{Cand}$. Nitrotoga neither grew better in $\mathrm{pH}$ of 6.4 than in 7.4, nor could it dominate over Nitrospira at low pH levels (Wegen et al. 2019). Accordingly, FISH-microautoradiography (MAR) of a nitrite-oxidizing enrichment showed that both NOB were active at a pH of 6.4 (Hüpeden 2016). Therefore, adaptation of Cand. Nitrotoga to low $\mathrm{pH}$ values cannot be generalized, and in summary, the $\mathrm{pH}$ value appeared less stringent for NOB selection than temperature.

\section{Influence of ammonium}

Some NOB of the phylum Chloroflexi (Nitrolancea, Cand. Nitrocaldera) turned out to require an external $\mathrm{N}$-source for assimilation, because genes for the reduction of nitrite to ammonium are missing (Sorokin et al. 2012; Spieck et al. 2020a, b). Similarly, reproducible growth of Cand. Nitrotoga sp. BS and AM1 could only be recovered by addition of ammonium (Ishii et al. 2017; Wegen et al. 2019). Ammonium auxotrophic Cand. Nitrotoga cells might have adapted to metabolic networks in nature, where nutrients are exchanged in bacterial communities (Pande and Kost 2017). This way, Cand. Nitrotoga sp. AM1P and BS could save energy for nitrite reduction to ammonium (Ishii et al. 2017). Other Cand. Nitrotoga representatives were not stimulated by ammonium and can grow on nitrite as sole nitrogen source (Boddicker and Mosier 2018; Kitzinger et al. 2018; Keuter et al. in preparation).

In Cand. Nitrotoga cultures, the tolerance limit for ammonium was 30-40 mM (Ishii et al. 2017; Wegen et al. 2019). Although this NOB could neither be found by FISH nor by specific PCR primers in reactor types receiving a very high ammonium influent as present for example in animal rendering (Lücker et al. 2015), in wastewater short-term experiments ( $24 \mathrm{~h})$, Cand. Nitrotoga survived in the presence of $1150 \mathrm{mg} \mathrm{L}^{-1}$ total ammonia nitrogen (TAN) $(\hat{=} 82 \mathrm{mM})$ (Li et al. 2020). In comparison, these concentrations are far below the activity inhibition value of ammonium measured for Nitrobacter (Hunik et al. 1993).

\section{Alternative metabolism}

Organic matter or other substrates are important if they are suitable to accelerate or replace growth on nitrite. The genome of Cand. Nitrotoga fabula contains a complete pathway for hydrogen oxidation as possible alternative energy source (Kitzinger et al. 2018), but presents a less flexible metabolism comparable to Nitrospira (Koch et al. 2014, 2015). Apart from the capacity for lithoautotrophic growth with nitrite as substrate and $\mathrm{CO}_{2}$ as carbon source, Cand. Nitrotoga strains can use simple organic substances as known for other NOB (Steinmüller and Bock 1976; Spieck 
et al. 2006). The nitrite oxidation rate was stimulated by pyruvate and lactate (Ishii et al. 2020) or acetate and dextrose (Boddicker and Mosier 2018) and Cand. N. fabula has a transporter system for branched amino acids (Kitzinger et al. 2018). Yet, it is not clear if the activity increase results from mixotrophic growth, or from hydrogen peroxide detoxification as known for AOA (Kim et al. 2016; Ishii et al. 2020). A study of Yi et al. (2019) investigated the response of the microbial community to changes in soil nutrients and found that Cand. Nitrotoga abundance was strongly positively correlated with total nitrogen, further suggesting the use of an elevated concentration of substrate and/or of organic matter released by the degradation of complex substances. In addition, genome annotations of Cand. Nitrotoga strains revealed that they carry genes for sulfite oxidation, which might be used as alternative energy source (Boddicker and Mosier 2018; Kitzinger et al. 2018). The use of sulfur compounds correlates with the metabolic repertoire of other NOB (Füssel et al. 2017; Lücker et al. 2013; Palomo et al. 2018; Starkenburg et al. 2008).

Urea is an important dissolved organic $\mathrm{N}$-compound in domestic wastewater (Hanson and Lee 1971) and RAS, where it may be $12-13 \%$ of the total dissolved nitrogen excreted by fish (Dalsgaard et al. 2015). The capacity for cleavage of urea was found in most Nitrospira (except $N$. defluvii) (Koch et al. 2015), but not in Cand. Nitrotoga (Boddicker and Mosier 2018; Kitzinger et al. 2018), supporting an advantage of the former NOB in the systems for water treatment.

Furthermore, Cand. Nitrotoga was one of the most prominent bacterial taxa (up to $6.8 \%$ of total bacteria) in anoxic/oxic reactor systems fed with acetate or glucose (Xing et al. 2018; Li et al. 2019). However, a possible denitrifying potential and mixotrophic or heterotrophic growth of Cand. Nitrotoga still require proofs from further experimental studies.

\section{Competition of Cand. Nitrotoga with Nitrospira and Nitrobacter}

The distribution of different NOB in the environment reflects the ecological niche differentiation based on distinct metabolic features. As a consequence, cultivation conditions have to be altered in order to meet requirements of specialized nitrifiers. For example, lowering the substrate concentration resulted in the enrichment of Nitrospira versus Nitrobacter from activated sludge and soils (Bartosch et al. 1999, 2002). Several other parameters that influence the composition of NOB communities were identified, like temperature, DO, pH, and salt (Alawi et al. 2009; Huang et al. 2010; Hüpeden et al. 2016; Navada et al. 2019). Since multiple environmental or operational parameters determine the composition of the NOB community, it is not easy to define conditions which support the dominance of Cand. Nitrotoga in a given habitat. Some parameters and applications which facilitated a high abundance of this NOB in water treatment are listed in Table 1 and table $\mathrm{S} 1$ and are discussed in the following sections. Screening of the literature was restricted to the name "Nitrotoga" which might lead to some bias in interpretation and underestimation of the global distribution, but enabled the most comprehensive view on these NOB.

\section{Low temperature}

The nitrifying community in most WWTPs consisted of Nitrospira as main NOB (Daims et al. 2006). Nevertheless, in a screening of WWTPs in Central Europe, Scandinavia, and North America, Cand. Nitrotoga turned out to belong to the core community and outcompeted Nitrospira in some of the plants (Lücker et al. 2015; Chen et al. 2020; Saunders et al. 2016). Its relative $16 \mathrm{~S}$ rRNA gene sequence abundance can reach $0.5-2 \%$ or even $4 \%$ (Johnston et al. 2019; Numberger et al. 2019; Saunders et al. 2016; Kruglova et al. 2020). In reactor systems for the treatment of ammoniacontaminated airstreams operated at $10{ }^{\circ} \mathrm{C}$, Cand. Nitrotoga constituted the only detected NOB (Gerrity et al. 2016). As

Table 1 Critical parameters for selection of Cand. Nitrotoga over Nitrospira (condensed version of table S1)

\begin{tabular}{lllll}
\hline Selective factor & Value & Molarity & Comment & Reference \\
\hline Low temperature & $\leq 17{ }^{\circ} \mathrm{C}$ & & Most strains & Alawi et al. 2009 \\
Low pH & $5.5-6.8$ & Some strains & Hüpeden et al. 2016 \\
High DO & $1-3 \mathrm{mg} \mathrm{L}^{-1}$ & $31-94 \mu \mathrm{M}$ & Lower affinity than Nitrospira & Zheng et al. 2020 \\
High nitrite & $4.2-420 \mathrm{mg} \mathrm{N} \mathrm{L}^{-1}$ & $0.3-30 \mathrm{mM}$ & Lower affinity than Nitrospira & Lücker et al. 2015; \\
& & & Nowka et al. 2015a \\
High FA & $220 \mathrm{mg} \mathrm{N} \mathrm{L}^{-1}$ & $15.7 \mathrm{mM}$ & Less inhibited than Nitrospira & Li et al. 2020 \\
High FNA & $1.8 \mathrm{mg} \mathrm{N} \mathrm{L}^{-1}$ & $0.13 \mathrm{mM}$ & Less inhibited than Nitrospira & Ma et al. 2017 \\
High sulfide & $\leq 20 \mathrm{mg} \mathrm{S} \mathrm{L}^{-1}$ & $<0.6 \mathrm{mM}$ & More resistant than Nitrospira & Delgado Vela et al. 2018 \\
\hline
\end{tabular}


mentioned above for natural habitats, its abundance often varied seasonally and temperature variations were identified as main environmental factor for niche occupation (Liu et al. 2021; Zhao et al. 2020). The highest cell numbers of Cand. Nitrotoga were observed in late winter or in spring (Keene et al. 2017; Miłobędzka and Muszyński 2017; Numberger et al. 2019; Kruglova et al. 2020; Kim et al. 2021) when the temperature is still too low for optimal growth of other NOB. A temperature-dependent shift in the NOB community was confirmed in a bioreactor experiment with inorganic mine waters (Table S1; Karkman et al. 2011). Other bioreactor experiments revealed that strains of Cand. Nitrotoga are able to compete with Nitrospira defluvii at a temperature of $17{ }^{\circ} \mathrm{C}$, but the abundance of Cand. Nitrotoga decreased when the temperature increased to $22{ }^{\circ} \mathrm{C}$ (Wegen et al. 2019).

A comparison of the seasonal nitrifying community between bench-scale and a lagoon WWTP in Canada revealed that the identified nitrifying bacteria (Nitrosomonas, Nitrospira, Cand. Nitrotoga) remained active even at low temperatures of $2-6{ }^{\circ} \mathrm{C}$ (Skoyles et al. 2020). Whereas Nitrospira dominated within the BioCord biofilm at benchscale, Cand. Nitrotoga was more abundant in the field samples where the NOB had to withstand day and night cycles with alternating temperatures. Investigations about $\mathrm{N}_{2} \mathrm{O}$ emissions in water treatment confirmed the importance of Cand. Nitrotoga for low temperature nitrification $\left(10-20{ }^{\circ} \mathrm{C}\right)$ during seasonal dynamics (Reino et al. 2017; Vieira et al. 2019; Gruber et al. 2021).

However, microautoradiography of activated sludge showed activity of Cand. Nitrotoga in a broad range from 4 to $27^{\circ} \mathrm{C}$ (Lücker et al. 2015), which indicated that the function of these NOB is not restricted to low temperature, and, as mentioned above, not all Cand. Nitrotoga strains are coldadapted or even psychrotolerant. For instance, close relatives of mesophilic Cand. Nitrotoga fabula were less competitive with Nitrospira at cold conditions and seem to be responsible for nitrite oxidation in warm water $\left(>20^{\circ} \mathrm{C}\right) \mathrm{N}$-removal systems as observed in China and Australia (Liu et al. 2021; Zheng et al. 2020; Petrovski et al. 2020; Table S1).

\section{Low DO}

Oxygen supply in large-scale WWTPs is expensive and oxygen limitation is a strategy to save energy but also needed for systems using anammox (anaerobic ammonia oxidation). The half-saturation constants for oxygen are far lower for Nitrospira than for Nitrobacter (Blackburne et al. 2007; Dytczak et al. 2008); for Cand. Nitrotoga these kinetic coefficients were not yet produced. In a partial nitritation-anammox (PNA) system for the treatment of municipal wastewater in Sweden, both Nitrospira and Cand. Nitrotoga resisted operation at intermittent aeration
(Gustavsson et al. 2020), which is founded in their adaptation to microaerophilic habitats (Boddicker and Mosier 2018; Lücker et al. 2010). However, in an SBR, Cand. Nitrotoga was found to have a lower affinity to dissolved oxygen than Nitrospira (Zheng et al. 2020; Table 1 and $\mathrm{S} 1$ ), and a stepwise increase of the DO level in a PNA reactor from 0.4 to $1.8 \mathrm{mg} \mathrm{L}^{-1}(13-56 \mu \mathrm{M})$ led to an increase of Cand. Nitrotoga versus Nitrospira (Qian et al. 2021), which confirmed the tolerance of Cand. Nitrotoga against DO mentioned above. A DO of $2-2.5 \mathrm{mg} \mathrm{L}^{-1}$ $(=62.5-78 \mu \mathrm{M})$ was evaluated as suitable condition for the out-selection of Nitrospira and Cand. Nitrotoga for partial nitrification-anammox (Jiang et al. 2018); therefore, intensive aeration has to be applied with caution when enrichment of Cand. Nitrotoga is required.

An experiment on artificial nitrifying biofilms in AS $\left(17{ }^{\circ} \mathrm{C}\right)$ revealed that thickness has a strong influence on the composition of the microbial community with $C$ and. Nitrotoga being almost restricted to thin biofilms $(50 \mu \mathrm{m})$, which can be fully oxygenated (Suarez et al. 2019). In contrast, Nitrospira also colonized a thick biofilm $(400 \mu \mathrm{m})$, which contained completely anoxic regions, with the highest abundance detected in $200 \mu \mathrm{m}$ depth. The biovolume fraction of Cand. Nitrotoga amounted to $2.7 \%$ in the $50 \mu \mathrm{m}$ biofilms, but only $0.5 \%$ in the $400 \mu \mathrm{m}$ biofilms (Piculell et al. 2016). These results demonstrate different responses to oxygen gradients of the NOB, as also shown by Zhang et al. (2018).

\section{High N-load}

Based on different substrate affinities mentioned above, Nitrospira is able to compete under low nitrite conditions, whereas Nitrobacter and Cand. Nitrotoga might benefit from higher substrate concentrations (Nowka et al. 2015a). This kind of competition was investigated by Kinnunen et al. (2017), who found that Cand. Nitrotoga outcompeted Nitrospira in a biofilm community at increased nitrite loading $\left(1 \mathrm{mg} \mathrm{N} \mathrm{L}^{-1}=70 \mu \mathrm{M}\right)$ and Nitrospira dominated at a tenfold lower substrate concentration. Likewise, using marker lipids for NOB community analyses in activated sludge, the Cand. Nitrotoga-typical fatty acid 16:1 cis 9 was labeled with ${ }^{13} \mathrm{C}$-bicarbonate at nitrite concentrations between 0.3 and $30 \mathrm{mM}$. In contrast, the fatty acid 16:1 cis 11 , which is characteristic for Nitrospira defluvii, showed ${ }^{13} \mathrm{C}$-incorporation in AS samples exposed to maximum $3 \mathrm{mM}$ nitrite (Kruse et al. 2013a). In addition to the substrate affinity, it was found that the competition between Nitrospira and Nitrobacter is also driven by the dilution rate (Winkler et al. 2017), but data for the minimal hydraulic retention time of Cand. Nitrotoga are rare. 


\section{FA and FNA}

Free ammonia (FA) and free nitrous acid (FNA) are known to cause severe inhibition to numerous bioprocesses in WWTPs and are gainfully used to suppress NOB in order to enhance partial nitrification in combination with anammox (Kim et al. 2006; Wang et al. 2016; Zhou et al. 2011; Yu et al. 2021). The inhibition thresholds for FA and FNA differ between NOB genera and Nitrobacter was less inhibited than Nitrospira (Blackburne et al. 2007; Duan et al. 2019). Cand. Nitrotoga can grow in the presence of relatively high concentrations of FA (up to $220 \mathrm{mg} \mathrm{NH}_{3}-\mathrm{N} \mathrm{L}^{-1}=15.7 \mathrm{mM}$; $\mathrm{Li}$ et al. 2020), which can be used as selective factor for enrichment (Ishii et al. 2017). In accordance, Cand. Nitrotoga became the dominant nitrite oxidizer, while Nitrospira was inhibited in water treatment under exposure to FNA and FA (Li et al. 2020; Zheng et al. 2020; Wang et al. 2021; Table 1 and S1). Similar to Nitrobacter, which revealed a

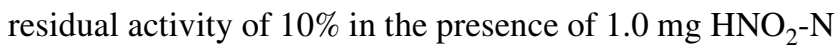
$\mathrm{L}^{-1}(71 \mu \mathrm{M})$ (Blackburne et al. 2007), Cand. Nitrotoga, but not Nitrospira, tolerated $1.87 \mathrm{mg} \mathrm{HNO}_{2}-\mathrm{N} \mathrm{L}^{-1}(134 \mu \mathrm{M}$; at a pH of 6.0) (Ma et al. 2017).

\section{Inhibition of NOB in water treatment}

Nitrite oxidation is a very sensitive process, which can cause a chaotic instability of the whole nitrification process (Graham et al. 2007). While this is unfavorable in conventional aerobic nitrification systems, a specific inhibition of NOB followed by accumulation of nitrite is the goal when partial nitritationanammox is used. For this purpose, an anaerobic pretreatment (Kouba et al. 2017a) or sulfide addition combined with a FA shock (see above) were used as stressors (Seuntjens et al. 2018). Other relevant factors which can suppress NOB are intensive aeration, high nitrate (low water exchange), salt addition (by the influent water), or chemicals (industrial wastewaters). Since Cand. Nitrotoga might be less affected than Nitrospira (or other NOB), the influence of some of these factors is discussed in the following.

\section{Nitrate accumulation}

Nitrate inhibition is of special interest in recirculating aquaculture systems, where no denitrification unit is installed. In accordance, nitrite oxidizers on biocarriers from marine and brackish RAS have shown decreased nitrification rates with increasing nitrate concentrations (Keuter 2011). Most Cand. Nitrotoga cultures oxidized nitrite with a reduced rate in the presence of 10-20 mM nitrate (Kitzinger et al. 2018; Wegen et al. 2019; Keuter et al. in preparation). This value is in the same range as those determined for Nitrospira lineage I+ II from AS (Nowka et al. 2015b), but much less than, e.g., for a marine Nitrospira isolated from a RAS (Keuter et al. 2011), Nitrospira moscoviensis (Ehrich et al. 1995), or Nitrobacter (Hunik et al. 1993). Although these levels should not be reached in RAS for the well-being of the reared animals (Camargo et al. 2005), they are not uncommon, and thus can be a factor shaping the nitrifying communities, in the worst case reducing nitrifying potentials of the biofilters.

\section{Salt inhibition}

Critical salinity changes are required in RAS, e.g., during the production of Atlantic salmon or in coastal wastewater collection systems, which are infiltrated by seawater (Kinyage et al. 2018). Salt inhibition of nitrification can also occur where municipal and industrial sewage is combined, and Nitrobacter and Nitrospira are known to resist osmotic stress (Hunik et al. 1993; Moussa et al. 2006; Qiu and Ting 2013).

The Cand. Nitrotoga strains in culture seem to tolerate only low salinity concentrations, even one isolated from coastal sediment (Ishii et al. 2017). Alone, a strain of Cand. Nitrotoga enriched from a biofilter of a marine RAS had optimal growth between 0.5 and $3 \% \mathrm{NaCl}$ (Keuter et al. in preparation). Nevertheless, Cand. Nitrotoga was resistant towards salt-spiked water $(1.5 \% \mathrm{NaCl})$ in bioreactor experiments (Karkman et al. 2011) and was the dominant NOB tolerating rising salinities up to $3.2 \%$ in freshwater moving bed bioreactors (Navada et al. 2019). It was concluded that $C$ and. Nitrotoga represents an important NOB in cold-water nitrifying systems with variable salinities (Navada et al. 2020a, b). These findings showed once again that physiological limits tested in cultures may differ from those in situ, and that $C a n d$. Nitrotoga is underrepresented by the few strains in culture so far.

\section{Sulfide inhibition}

Hydrogen sulfide is produced biologically from sulfate in sewers and in anaerobic niches within treatment plants (Delgado Vela et al. 2018), and is discussed as electron donor for denitrification. Since sulfide especially inhibits NOB, it is used to establish partial nitritation/anammox (Kouba et al. 2017b). Batch experiments revealed that sulfide inhibition of nitrite oxidation depends on the microbial community and a Nitrospira-rich community was more inhibited than a community containing Cand. Nitrotoga and Nitrobacter (Delgado Vela et al. 2018). After a treatment of $150 \mathrm{mg} \mathrm{S} \mathrm{L}^{-1}(4.7 \mathrm{mM})$, Cand. Nitrotoga was more resilient than Nitrospira (Seuntjens et al. 2018) and a similarly high tolerance level (128 $\mathrm{mg} \mathrm{S} \mathrm{L}^{-1}$ or $4 \mathrm{mM}$ ) was reported for Nitrobacter (Sekine et al. 2020). Correspondingly, Maestre et al. (2009) investigated the bacterial community in a biotrickling filter treating high loads of $\mathrm{H}_{2} \mathrm{~S}$ and found a 
Cand. Nitrotoga fabula-like 16S rRNA gene sequence cluster, which might belong to resistant NOB.

\section{Resistance against chemicals and reactive oxygen species}

Cand. Nitrotoga have repeatedly been found at contaminated sites like polluted rivers, petrochemical, or antibiotics-contaminated wastewaters (Brümmer et al. 2003; Li et al. 2011; Song et al. 2020). Their abundance was low in oil sands tailing ponds (Ramos-Padrón et al. 2011) but they belong to the dominant genera in biodegradation of naphthenic acids in process waters of oil sands (McKenzie et al. 2014). Notably, Zeman et al. (2014) concluded that Cand. Nitrotoga might be a novel hydrocarbon degrader due to the high relative abundance of $42 \%$ after a 12 -month incubation at $30{ }^{\circ} \mathrm{C}$. Survival in contaminated environments might be facilitated by an array of antibiotic and metal resistance genes in these organisms (Boddicker and Mosier 2018; Kitzinger et al. 2018). Several antibiotics were tested on cultures, and used in isolation procedures of this NOB (Ishii et al. 2020). When the effect of chromium for $\mathrm{N}$-removal of granular sludge was investigated, Cand. Nitrotoga was able to tolerate $5 \mathrm{mg} \mathrm{Cr}$ (VI) $\mathrm{L}^{-1}(96 \mu \mathrm{M})$ which otherwise has a strong negative impact on NOB (Zheng et al. 2018).

With respect to their genomic interior, Cand. Nitrotoga should be able to resist oxidative stress to a certain degree (Boddicker and Mosier 2018; Ishii et al. 2020). This might be of relevance for dewatering sewage or disinfection in RAS with $\mathrm{H}_{2} \mathrm{O}_{2}$ (Alasri et al. 1992; Yang et al. 2018), but detailed studies on cultures were not performed so far. On the other hand, a low-dose UVA irradiation was successfully applied as new approach to eliminate NOB (Nitrospira and Cand. Nitrotoga) for N-removal via anammox (Chu et al. 2020).

\section{Possible application of Cand. Nitrotoga in phosphorus removal?}

To protect receiving waters from eutrophication, municipal wastewater treatment plants have to remove not only excess nitrogen but also phosphorus. The process relies on a diverse bacterial community, which is able to store phosphorus intracellulary (Lawson et al. 2015). A novel polyphosphate accumulating organisms in domestic sewage (NCBI Accession number AB247475) was found with a high level of $16 \mathrm{~S}$ rRNA gene sequence identity (99.0\%) to Cand. N. arctica 6680. The novel nitrite oxidizing betaproteobacterium was further detected in several biological phosphorus removal plants (Kong et al. 2007; Ji and Chen 2010; Keene et al. 2017) and represented the only NOB in nitrifying-denitrifying phosphorus-accumulating granules in an activated sludge system operated at $12{ }^{\circ} \mathrm{C}$ (Figdore et al. 2018). Furthermore, both, Cand. Nitrotoga and Nitrospira, were found in low numbers in an enhanced biological phosphorus removal bioreactor (EBPR, $13-20{ }^{\circ} \mathrm{C}$ ), but only Cand. Nitrotoga remained active during 120 days of operation with large changes of operational parameters across the different bioreactor redox zones (Lawson et al. 2015). These findings hint to a possible involvement of Cand. Nitrotoga in the phosphorus cycle and genes for phosphorus storage were found in some Cand. Nitrotoga strains (Boddicker and Mosier 2018; Ishii et al. 2020) as already known for other NOB. Additionally, electron-dense granules assumed to represent polyphosphate were observed in high numbers in cells of Cand. Nitrotoga in activated sludge (Alawi et al. 2009). Whether Cand. Nitrotoga have indeed a function in phosphorus removal in water treatment warrants further attention.

In general, NOB are survivalists supported by the storage of diverse reserve material. Nitrobacter uses polyphosphate as metabolic buffer (Eigener and Bock 1972) and C-storage compounds like poly-ß-hydroxybutyrate (PHB) and glycogen (van Gool et al. 1971). Glycogen deposits are present in all NOB, which was confirmed by genomic analyses for Cand. Nitrotoga (Kitzinger et al. 2018; Ishii et al. 2020). Notably, the combined removal of nitrogen and phosphorus with C-storage (PHA) at low temperature and participation of Cand. Nitrotoga seems promising at low $\mathrm{C} / \mathrm{N}$ ratio (Yang et al. 2019).

\section{Microdiversity of Cand. Nitrotoga populations}

In two reported cases, different strains of Cand. Nitrotoga have been enriched from the same source material (Ishii et al. 2020; Wegen et al. 2019), and these strains appeared to be adapted to differing nitrite concentration or temperatures. This could be an example of ecological niche separation in Cand. Nitrotoga, similar to previous findings in Nitrospira (Maixner et al. 2006). Diversity within the genus based on niche differentiation is still a new avenue for $C$ and. Nitrotoga-focused research, but experiments that used contrasting substrate conditions let us suggest that respectively different Cand. Nitrotoga strains are active in the same habitat (Kruse et al. 2013a; Lücker et al. 2015). Molecular surveys of biofilm communities in RAS or flow-through microcosms could differentiate between several representatives of Cand. Nitrotoga and the resident strain could not be replaced by invaders of the same genus despite their low phylogenetic distance (Navada et al. 2020a; Kinnunen et al. 2018). The coexistence of multiple NOB, even if they are 
closely related, supports stabilization of the system in case of disturbances (Santillan et al. 2020).

\section{Conclusion}

The perception that nitrite oxidation at low temperature is mainly driven by highly specialized bacteria of Cand. Nitrotoga was confirmed by cultivation-based studies, metagenomic surveys, and biotechnological experiments. The phylogenetic distinct nitrite oxidoreductase points to a separate evolution event, and despite the same orientation in the periplasmic space, Cand. Nitrotoga and Nitrospira differ in their substrate affinity and carbon fixation pathway. Consequently, these competitors can be separated by selected nitrite concentrations and elevated $\mathrm{DO}$, which can be used to stabilize low-temperature nitrification processes. In terms of inhibition of NOB for partial nitrification/anammox, the robust Cand. Nitrotoga is highly resistant against treatment with FA and FNA, exposure to sulfide, and toxicants and survives harsh conditions similar to Nitrobacter. Therefore, Cand. Nitrotoga is a suitable candidate for nitrite oxidation under stress as necessary for the treatment of industrial sewage.

In contrast to other NOB, Cand. Nitrotoga occupies its own physiological niche of low temperature and is therefore an important NOB for $\mathrm{N}$-removal in natural and engineered ecosystems which are influenced by seasonal temperature fluctuations. It often is not permanently prevalent like Nitrospira, but rather reveals a "bloomy" distribution when conditions are advantageous in competition with other NOB.

In future, genome analyses might give further hints for additional physiological capacities of this NOB. Identification of the promoting factors for growth of Cand. Nitrotoga (e.g., elevated $\mathrm{CO}_{2}$ concentrations, organic matter, iron) provides the background for advanced nitrogen removal techniques. Especially cycling between anaerobic and aerobic incubation for enhanced biologically phosphorus removal (EBPR) is a worthwhile matter of future research.

Supplementary Information The online version contains supplementary material available at https://doi.org/10.1007/s00253-021-11487-5.

Acknowledgements The authors thank Elke Woelken for excellent technical help in electron microscopy. We also greatly appreciate the suggestions of two anonymous reviewers, which improved the manuscript significantly.

Author contribution ES screened the literature and wrote the manuscript, SK critically edited the review and prepared the figures; SW provided figures and data. All authors approved the manuscript.

Funding Open Access funding enabled and organized by Projekt DEAL. This work was supported by the Deutsche Forschungsgemeinschaft (DFG, German Research Foundation grant SP 667/10-2 and grant SP 667/11-1).

\section{Declarations}

Ethics approval This article does not contain any studies with human participants or animals performed by the authors.

Conflict of interest The authors declare no competing interests.

Open Access This article is licensed under a Creative Commons Attribution 4.0 International License, which permits use, sharing, adaptation, distribution and reproduction in any medium or format, as long as you give appropriate credit to the original author(s) and the source, provide a link to the Creative Commons licence, and indicate if changes were made. The images or other third party material in this article are included in the article's Creative Commons licence, unless indicated otherwise in a credit line to the material. If material is not included in the article's Creative Commons licence and your intended use is not permitted by statutory regulation or exceeds the permitted use, you will need to obtain permission directly from the copyright holder. To view a copy of this licence, visit http://creativecommons.org/licenses/by/4.0/.

\section{References}

Achberger AM, Christner BC, Michaud AB, Priscu JC, Skidmore ML, Vick-Majors TJ, Adkins W, Anandakrishnan S, Barbante C, Barcheck G, Beem L, Behar A, Beitch M, Bolsey R, Branecky C, Carter S, Christianson K, Edwards R, Fisher A, Fricker H, Foley N, Guthrie B, Hodson T, Jacobel R, Kelley S, Mankoff K, McBryan E, Mikucki J, Mitchell A, Powell R, Purcell A, Sampson D, Scherer R, Sherve J, Siegfried M, Tulaczyk S (2016) Microbial community structure of subglacial Lake Whillans, West Antarctica. Front Microbiol 7:1457. https://doi.org/10. 3389/fmicb.2016.01457

Alasri A, Roques C, Michel G, Cabassud C, Aptel P (1992) Bactericidal properties of peracetic acid and hydrogen peroxide, alone and in combination, and chlorine and formaldehyde against bacterial water strains. Can J Microbiol 38:635-642. https://doi.org/ 10.1139/m92-104

Alawi M, Lipski A, Sanders T, Eva-Maria-Pfeiffer SE (2007) Cultivation of a novel cold-adapted nitrite oxidizing betaproteobacterium from the Siberian Arctic. ISME J 1:256-264. https://doi. org/10.1038/ismej.2007.34

Alawi M, Off S, Kaya M, Spieck E (2009) Temperature influences the population structure of nitrite-oxidizing bacteria in activated sludge. Environ Microbiol Rep 1:184-190. https://doi.org/10. $1111 / j .1758-2229.2009 .00029 . x$

Albers CN, Ellegaard-Jensen L, Hansen LH, Sørensen SR (2018) Bioaugmentation of rapid sand filters by microbiome priming with a nitrifying consortium will optimize production of drinking water from groundwater. Water Res 129:1-10. https://doi.org/ 10.1016/j.watres.2017.11.009

Bartosch S, Wolgast I, Spieck E, Bock E (1999) Identification of nitriteoxidizing bacteria with monoclonal antibodies recognizing the nitrite oxidoreductase. Appl Environ Microbiol 65:4126-4133

Bartosch S, Hartwig C, Spieck E, Bock E (2002) Immunological detection of Nitrospira-like bacteria in various soils. Microb Ecol 43:26-33. https://doi.org/10.1007/s00248-001-0037-5

Bayer B, Saito MA, McIlvin MR, Lücker S, Moran DM, Lankiewicz TS, Dupont CL, Santoro AE (2021) Metabolic versatility of the nitrite-oxidizing bacterium Nitrospira marina and its proteomic response to oxygen-limited conditions. ISME J 15:1025-1039. https://doi.org/10.1038/s41396-020-00828-3 
Berg IA (2011) Ecological aspects of the distribution of different autotrophic CO2 fixation pathways. Appl Environ Microbiol 77:1925-1936. https://doi.org/10.1128/AEM.02473-10

Blackburne R, Vadivelu VM, Yuan Z, Keller J (2007) Kinetic characterisation of an enriched Nitrospira culture with comparison to Nitrobacter. Water Res 41:3033-3042

Boddicker AM, Mosier AC (2018) Genomic profiling of four cultivated Candidatus Nitrotoga spp. predicts broad metabolic potential and environmental distribution. ISME J 12:2864-2882. https://doi. org/10.1038/s41396-018-0240-8

Brümmer IHM, Felske A, Wagner-Döbler I (2003) Diversity and seasonal variability of beta-Proteobacteria in biofilms of polluted rivers: analysis by temperature gradient gel electrophoresis and cloning. Appl Environ Microbiol 69:4463-4473. https://doi.org/ 10.1128/aem.69.8.4463-4473.2003

Camargo JA, Alonso Á (2006) Ecological and toxicological effects of inorganic nitrogen pollution in aquatic ecosystems: a global assessment. Environ Int 32:831-849. https://doi.org/10.1016/j. envint.2006.05.002

Camargo JA, Alonso A, Salamanca A (2005) Nitrate toxicity to aquatic animals: a review with new data for freshwater invertebrates. Chemosphere 58:1255-2126. https://doi.org/10.1016/j.chemo sphere.2004.10.044

Cai Y, Li D, Liang Y, Zeng H, Zhang J (2016) Operational parameters required for the start-up process of a biofilter to remove $\mathrm{Fe}, \mathrm{Mn}$, and NH3-N from low-temperature groundwater. Desalin Water Treat 57:3588-3596. https://doi.org/10.1080/19443994.2014. 986203

Chen Y, Wu L, Boden R, Hillebrand A, Kumaresan D, Moussard H, Baciu M, Lu Y, Colin Murrell J (2009) Life without light: microbial diversity and evidence of sulfur- and ammonium-based chemolithotrophy in Movile Cave. ISME J 3:1093-1104. https:// doi.org/10.1038/ismej.2009.57

Chen H, Wang M, Chang S (2020) Disentangling community structure of ecological system in activated sludge: core communities, functionality, and functional redundancy. Microb Ecol 80:296-308. https://doi.org/10.1007/s00248-020-01492-y

Christner BC, Priscu JC, Achberger AM, Barbante C, Carter SP, Christianson K, Michaud AB, Mikucki JA, Mitchell AC, Skidmore ML, Vick-Majors TJ, Adkins WP, Anandakrishnan S, Barcheck G, Beem L, Behar A, Beitch M, Bolsey R, Branecky C, Edwards R, Fisher A, Fricker HA, Foley N, Guthrie B, Hodson T, Horgan H, Jacobel R, Kelley S, Mankoff KD, McBryan E, Powell R, Purcell A, Sampson D, Scherer R, Sherve J, Siegfried M, Tulaczyk S, Team the WS (2014) A microbial ecosystem beneath the West Antarctic ice sheet. Nature 512:310-313. https://doi.org/ 10.1038/nature13667

Chu Z, Huang X, Su Y, Yu H, Rong H, Wang R, Zhang L (2020) Low-dose Ultraviolet-A irradiation selectively eliminates nitrite oxidizing bacteria for mainstream nitritation. Chemosphere 261:128172. https://doi.org/10.1016/j.chemosphere.2020.128172

Cohen Y, Pasternak Z, Johnke J, Abed-Rabbo A, Kushmaro A, Chatzinotas A, Jurkevitch E (2019) Bacteria and microeukaryotes are differentially segregated in sympatric wastewater microhabitats. Environ Microbiol 21:1757-1770. https://doi.org/10.1111/14622920.14548

Cruaud P, Vigneron A, Fradette M-S, Dorea CC, Culley AI, Rodriguez MJ, Charette SJ (2020) Annual bacterial community cycle in a seasonally ice-covered river reflects environmental and climatic conditions. Limnol Oceanogr 65:S21-S37. https://doi.org/10. 1002/Ino.11130

Daims H, Maixner F, Lucker S, Stoecker K, Hace K, Wagner M (2006) Ecophysiology and niche differentiation of Nitrospira-like bacteria, the key nitrite oxidizers in wastewater treatment plants. Water Sci Technol 54:21-27. https://doi.org/10.2166/wst.2006.367
Daims H, Lebedeva EV, Pjevac P, Han P, Herbold C, Albertsen M, Jehmlich N, Palatinszky M, Vierheilig J, Bulaev A, Kirkegaard RH, Von Bergen M, Rattei T, Bendinger B, Nielsen PH, Wagner M (2015) Complete nitrification by Nitrospira bacteria. Nature 528:504-509. https://doi.org/10.1038/nature16461

Daims H, Lücker S, Wagner M (2016) A new perspective on microbes formerly known as nitrite-oxidizing bacteria. Trends Microbiol 24:699-712. https://doi.org/10.1016/j.tim.2016.05.004

Dalsgaard J, Larsen BK, Pedersen PB (2015) Nitrogen waste from rainbow trout (Oncorhynchus mykiss) with particular focus on urea. Aquac Eng 65:2-9. https://doi.org/10.1016/j. aquaeng.2014. 10.004

Delgado Vela J, Dick GJ, Love NG (2018) Sulfide inhibition of nitrite oxidation in activated sludge depends on microbial community composition. Water Res 138:241-249. https://doi.org/10.1016/j. watres.2018.03.047

Dempsey M (2017) Nitrification at low temperature for purification of used water. In: Margesin R (ed) Psychrophiles: From biodiversity to biotechnology, 2nd edn. Springer International Publishing, New York, pp 601-612

Downing LS, Nerenberg R (2008) Effect of oxygen gradients on the activity and microbial community structure of a nitrifying, membrane-aerated biofilm. Biotechnol Bioeng 101:1193-1204. https://doi.org/10.1002/bit.22018

Dytczak MA, Londry KL, Oleszkiewicz JA (2008) Activated sludge operational regime has significant impact on the type of nitrifying community and its nitrification rates. Water Res 42:23202328. https://doi.org/10.1016/j.watres.2007.12.018

Duan H, Ye L, Lu X, Yuan Z (2019) Overcoming nitrite oxidizing bacteria adaptation through alternating sludge treatment with free nitrous acid and free ammonia. Environ Sci Technol 53:1937-1946. https://doi.org/10.1021/acs.est.8b06148

Ehrich S, Behrens D, Lebedeva E, Ludwig W, Bock E (1995) A new obligately chemolithoautotrophic, nitrite-oxidizing bacterium, Nitrospira moscoviensis sp. nov. and its phylogenetic relationship. Arch Microbiol 164:16-23. https://doi.org/10.1007/ BF02568729

Eigener U, Bock E (1972) Auf- und Abbau der Polyphosphatfraktion in Zellen von Nitrobacter winogradskyi Buch. Arch Mikrobiol 81:367-378

Elling FJ, Evans TW, Hemingway JD, Kharbush JJ, Nathan V, Bayer B, Santoro AE, Spieck E, Summons RE, Pearson A (submitted) Marine and terrestrial nitrifying bacteria are sources of diverse bacteriohopanepolyols

Fan L, Song C, Meng S, Qiu L, Zheng Y, Wu W, Qu J, Li D, Zhang C, Hu G, Chen J (2016) Spatial distribution of planktonic bacterial and archaeal communities in the upper section of the tidal reach in Yangtze River. Sci Rep 6:39147. https://doi.org/10.1038/ srep39147

Figdore BA, David Stensel H, Winkler MKH (2018) Bioaugmentation of sidestream nitrifying-denitrifying phosphorus-accumulating granules in a low-SRT activated sludge system at low temperature. Water Res 135:241-250. https://doi.org/10. 1016/j.watres.2018.02.035

Foesel BU, Gieseke A, Schwermer C, Stief P, Koch L, Cytryn E, de la Torre JR, van Rijn J, Minz D, Drake HL, Schramm A (2008) Nitrosomonas Nm143-like ammonia oxidizers and Nitrospira marina-like nitrite oxidizers dominate the nitrifier community in a marine aquaculture biofilm. FEMS Microbiol Ecol 63:192-204

Fournier IB, Lovejoy C, Vincent WF (2021) Changes in the community structure of under-ice and open-water microbiomes in urban lakes exposed to road salts. Front Microbiol 12:1-18. https://doi. org/10.3389/fmicb.2021.660719

Füssel J, Lücker S, Yilmaz P, Nowka B, van Kessel MAHJ, Bourceau P, Hach PF, Littmann S, Berg J, Spieck E, Daims H, Kuypers 
MMM, Lam P (2017) Adaptability as the key to success for the ubiquitous marine nitrite oxidizer Nitrococcus. Sci Adv 3:e1700807. https://doi.org/10.1126/sciadv.1700807

Gerrity S, Clifford E, Kennelly C, Collins G (2016) Ammonia oxidizing bacteria and archaea in horizontal flow biofilm reactors treating ammonia-contaminated air at $10{ }^{\circ} \mathrm{C}$. J Ind Microbiol Biotechnol 43:651-661. https://doi.org/10.1007/s10295-016-1740-z

Graham DW, Knapp CW, Van Vleck ES, Bloor K, Lane TB, Graham CE (2007) Experimental demonstration of chaotic instability in biological nitrification. ISME J 1:385-393

Gruber W, Niederdorfer R, Ringwald J, Morgenroth E, Buergmann H, Joss A (2021) Linking seasonal $\mathrm{N}_{2} \mathrm{O}$ emissions and nitrification failures to microbial dynamics in a SBR wastewater treatment plant. Water Res X 11:100098. https://doi.org/10.1016/j.wroa. 2021.100098

Gustavsson DJI, Suarez C, Wilén BM, Hermansson M, Persson F (2020) Long-term stability of partial nitritation-anammox for treatment of municipal wastewater in a moving bed biofilm reactor pilot system. Sci Total Environ 714:136342. https://doi.org/ 10.1016/j.scitotenv.2019.136342

Hanson AM, Lee GF (1971) Forms of organic nitrogen in domestic wastewater. J Water Pollut Control Fed 43:2271-2279

Huang Z, Gedalanga PB, Asvapathanagul P, Olson BH (2010) Influence of physicochemical and operational parameters on Nitrobacter and Nitrospira communities in an aerobic activated sludge bioreactor. Water Res 44:4351-4358. https://doi.org/10.1016/j. watres.2010.05.037

Hunik JH, Meijer HJG, Tramper J (1993) Kinetics of Nitrobacter agilis at extreme substrate, product and salt concentrations. Appl Microbiol Biotechnol 40:442-448. https://doi.org/10.1007/ BF00170408

Hüpeden J (2016) Taxonomic and functional diversity of nitrifying biofilm communities in biofilters of different recirculating aquaculture systems. Dissertation. University of Hamburg

Hüpeden J, Wegen S, Off S, Lücker S, Bedarf Y, Daims H, Kühn C, Spieck E (2016) Relative abundance of Nitrotoga spp. in a biofilter of a cold-freshwater aquaculture plant appears to be stimulated by slightly acidic pH. Appl Environ Microbiol 82:18381845. https://doi.org/10.1128/AEM.03163-15

Hüpeden J, Wemheuer B, Indenbirken D, Schulz C, Spieck E (2020) Taxonomic and functional profiling of nitrifying biofilms in freshwater, brackish and marine RAS biofilters. Aquac Eng 90:102094. https://doi.org/10.1016/j.aquaeng.2020.102094

Ionescu D, Heim C, Polerecky L, Ramette A, Haeusler S, Bizic-Ionescu M, Thiel V, de Beer D (2015) Diversity of iron oxidizing and reducing bacteria in flow reactors in the Äspö Hard Rock Laboratory. Geomicrobiol J 32:207-220. https://doi.org/10.1080/01490 451.2014.884196

Ishii K, Fujitani H, Sekiguchi Y, Tsuneda S (2020) Physiological and genomic characterization of a new 'Candidatus Nitrotoga' isolate. Environ Microbiol 22:2365-2382. https://doi.org/10.1111/ 1462-2920.15015

Ishii K, Fujitani H, Soh K, Nakagawa T, Takahashi R, Tsuneda S (2017) Enrichment and physiological characterization of a coldadapted nitrite-oxidizing Nitrotoga sp. from an eelgrass sediment. Appl Environ Microbiol 83:e00549-e617. https://doi.org/ 10.1128/AEM.00549-17

Ji Z, Chen Y (2010) Using sludge fermentation liquid to improve wastewater short-cut nitrification-denitrification and denitrifying phosphorus removal via nitrite. Environ Sci Technol 44:8957-8963. https://doi.org/10.1021/es102547n

Jiang H, Liu G, Ma Y, Xu X, Chen J, Yang Y, Liu X, Wang H (2018) A pilot-scale study on start-up and stable operation of mainstream partial nitrification-anammox biofilter process based on online pH-DO linkage control. Chem Eng J 350:1035-1042. https://doi. org/10.1016/j.cej.2018.06.007
Johnston J, LaPara T, Behrens S (2019) Composition and dynamics of the activated sludge microbiome during seasonal nitrification failure. Sci Rep 9:4565. https://doi.org/10.1038/ s41598-019-40872-4

Kaarela O, Härkki H, Palmroth M, Tuhkanen T (2015) Bacterial diversity and active biomass in full-scale granular activated carbon filters operated at low water temperatures. Environ Technol 36:681-692. https://doi.org/10.1080/09593330.2014.958542

Karkman A, Mattila K, Tamminen M, Virta M (2011) Cold temperature decreases bacterial species richness in nitrogen-removing bioreactors treating inorganic mine waters. Biotechnol Bioeng 108:2876-2883. https://doi.org/10.1002/bit.23267

Keene NA, Reusser SR, Scarborough MJ, Grooms AL, Seib M, Santo Domingo J, Noguera DR (2017) Pilot plant demonstration of stable and efficient high rate biological nutrient removal with low dissolved oxygen conditions. Water Res 121:72-85. https:// doi.org/10.1016/j.watres.2017.05.029

Keuter S (2011) Characterization of nitrifying bacteria in marine recirculation aquaculture systems with regard to process optimization. Dissertation. University of Hamburg

Keuter S, Kruse M, Lipski A, Spieck E (2011) Relevance of Nitrospira for nitrite oxidation in a marine recirculation aquaculture system and physiological features of a Nitrospira marinalike isolate. Env Microbiol 13:2536-2547. https://doi.org/10. 1111/j.1462-2920.2011.02525.x

Keuter S, Beth S, Quantz G, Schulz C, Spieck E (2017) Long-term monitoring of nitrification and nitrifying communities during biofilter activation of two marine recirculation aquaculture systems (RAS). Int J Aquac Fish Sci 3:051-061. https://doi.org/ 10.17352/2455-8400.000029

Keuter S, Koch H, Saß K, Wegen S, Lee N, Lücker S, Spieck E (in preparation) A closer look into the cellular organization, physiological limits, and phylogenetic diversity of cold-tolerant nitriteoxidizing Nitrotoga

Kim DJ, Lee DI, Keller J (2006) Effect of temperature and free ammonia on nitrification and nitrite accumulation in landfill leachate and analysis of its nitrifying bacterial community by FISH. Bioresour Technol 97:459-468

Kim JG, Park SJ, Sinninghe Damsté JS, Schouten S, Rijpstra WIC, Jung MY, Kim SJ, Gwak JH, Hong H, Si OJ, Lee S, Madsen EL, Rhee SK (2016) Hydrogen peroxide detoxification is a key mechanism for growth of ammonia-oxidizing archaea. Proc Natl Acad Sci U S A 113:7888-7893. https://doi.org/10.1073/ pnas. 1605501113

Kim T, Hite M, Rogacki L, Sealock AW, Sprouse G, Novak PJ, LaPara TM (2021) Dissolved oxygen concentrations affect the function but not the relative abundance of nitrifying bacterial populations in full-scale municipal wastewater treatment bioreactors during cold weather. Sci Total Environ 781:146719. https://doi.org/10.1016/j.scitotenv.2021.146719

Kinnunen M, Gülay A, Albrechtsen HJ, Dechesne A, Smets BF (2017) Nitrotoga is selected over Nitrospira in newly assembled biofilm communities from a tap water source community at increased nitrite loading. Environ Microbiol 19:2785-2793. https://doi.org/10.1111/1462-2920.13792

Kinnunen M, Dechesne A, Albrechtsen HJ, Smets BF (2018) Stochastic processes govern invasion success in microbial communities when the invader is phylogenetically close to resident bacteria. ISME J 12:2748-2756. https://doi.org/10.1038/ s41396-018-0202-1

Kinyage J, Pedersen P, Pedersen L-F (2018) Effects of abrupt salinity increase on nitrification processes in a freshwater moving bed biofilter. Aquac Eng 84:91-98. https://doi.org/10.1016/j. aquaeng.2018.12.005

Kirstein K, Bock E (1993) Close genetic relationship between Nitrobacter hamburgensis nitrite oxidoreductase and Escherichia 
coli nitrate reductases. Arch Microbiol 160:447-453. https:// doi.org/10.1007/BF00245305

Kitzinger K, Koch H, Lücker S, Sedlacek CJ, Herbold C, Schwarz J, Daebeler A, Mueller AJ, Lukumbuzya M, Romano S, Leisch N, Karst SM, Kirkegaard R, Albertsen M, Nielsen PH, Wagner M, Daims H (2018) Characterization of the first "Candidatus Nitrotoga" isolate reveals metabolic versatility and separate evolution of widespread nitrite-oxidizing bacteria. Mbio 9:e01186-e1218. https://doi.org/10.1128/mBio.01186-18

Koch H, Galushko A, Albertsen M, Schintlmeister A, Gruber-Dorninger C, Lücker S, Pelletier E, Le Paslier D, Spieck E, Richter A, Nielsen PH, Wagner M, Daims H (2014) Microbial metabolism: growth of nitrite-oxidizing bacteria by aerobic hydrogen oxidation. Science 345:1052-1054. https://doi.org/10.1126/ science. 1256985

Koch H, Lücker S, Albertsen M, Kitzinger K, Herbold C, Spieck E, Nielsen PH, Wagner M, Daims H (2015) Expanded metabolic versatility of ubiquitous nitrite-oxidizing bacteria from the genus Nitrospira. Proc Natl Acad Sci U S A 112:11371-11376. https://doi.org/10.1073/pnas.1506533112

Kohler TJ, Vinšová P, Falteisek L, Žárský JD, Yde JC, Hatton JE, Hawkings JR, Lamarche-Gagnon G, Hood E, Cameron KA, Stibal M (2020) Patterns in microbial assemblages exported from the meltwater of Arctic and sub-Arctic glaciers. Front Microbiol 11:669. https://doi.org/10.3389/fmicb.2020.00669

Koops H-P, Pommerening-Röser A (2001) Distribution and ecophysiology of the nitrifying bacteria emphasizing cultured species. FEMS Microbiol Ecol 37:1-9. https://doi.org/10.1111/j.15746941.2001.tb00847.x

Kong Y, Xia Y, Nielsen JL, Nielsen PH (2007) Structure and function of the microbial community in a full-scale enhanced biological phosphorus removal plant. Microbiology 153:4061-4073. https:// doi.org/10.1099/mic.0.2007/007245-0

Kouba V, Vejmelkova D, Proksova E, Wiesinger H, Concha M, Dolejs P, Hejnic J, Jenicek P, Bartacek J (2017a) High-rate partial nitritation of municipal wastewater after psychrophilic anaerobic pretreatment. Environ Sci Technol 51:11029-11038. https://doi.org/ 10.1021/acs.est.7b02078

Kouba V, Proksova E, Wiesinger H, Vejmelkova D, Bartacek J (2017b) Good servant, bad master: sulfide influence on partial nitritation of sewage. Water Sci Technol 76:3258-3268. https://doi.org/10. 2166/wst.2017.490

Krauze P, Kämpf H, Horn F, Liu Q, Voropaev A, Wagner D, Alawi M (2017) Microbiological and geochemical survey of $\mathrm{CO}_{2}$-dominated mofette and mineral waters of the Cheb basin, Czech Republic. Front Microbiol 8:2446. https://doi.org/10. 3389/fmicb.2017.02446

Kruglova A, Kesulahti J, Le KM, Gonzalez-Martinez A, Mikola A, Vahala R (2020) Low-temperature adapted nitrifying microbial communities of Finnish wastewater treatment systems. Water (Switzerland) 12:2450. https://doi.org/10.3390/w12092450

Kruse M, Zumbrägel S, Bakker E, Spieck E, Eggers T, Lipski A (2013a) The nitrite-oxidizing community in activated sludge from a municipal wastewater treatment plant determined by fatty acid methyl ester-stable isotope probing. Syst Appl Microbiol 36:517-524. https://doi.org/10.1016/j.syapm.2013.06.007

Kruse M, Keuter S, Bakker E, Spieck E, Eggers T, Lipski A (2013b) Relevance and diversity of Nitrospira populations in biofilters of brackish RAS. PLoS ONE 8:e64737. https://doi.org/10.1371/ journal.pone. 0064737

Lawson CE, Strachan BJ, Hanson NW, Hahn AS, Hall ER, Rabinowitz B, Mavinic DS, Ramey WD, Hallam SJ (2015) Rare taxa have potential to make metabolic contributions in enhanced biological phosphorus removal ecosystems. Environ Microbiol 17:49794993. https://doi.org/10.1111/1462-2920.12875
Li D, Qi R, Yang M, Zhang Y, Yu T (2011) Bacterial community characteristics under long-term antibiotic selection pressures. Water Res 45:6063-6073. https://doi.org/10.1016/j.watres.2011.09.002

Li S, Fei X, Cao L, Chi Y (2019) Insights into the effects of carbon source on sequencing batch reactors: performance, quorum sensing and microbial community. Sci Total Environ 691:799-809. https://doi.org/10.1016/j.scitotenv.2019.07.191

Li S, Duan H, Zhang Y, Huang X, Yuan Z, Liu Y, Zheng M (2020) Adaptation of nitrifying community in activated sludge to free ammonia inhibition and inactivation. Sci Total Environ 728:138713. https://doi.org/10.1016/j.scitotenv.2020.138713

Liu Y, Li S, Ni G, Duan H, Huang X, Yuan Z, Zheng M (2021) Temperature variations shape niche occupation of Nitrotoga -like bacteria in activated sludge. ACS EST Water 1:167-174. https://doi. org/10.1021/acsestwater.0c00060

Lücker S, Nowka B, Rattei T, Spieck E, Daims H (2013) The genome of Nitrospina gracilis illuminates the metabolism and evolution of the major marine nitrite oxidizer. Front Microbiol 4. https:// doi.org/10.3389/fmicb.2013.00027

Lücker S, Schwarz J, Gruber-Dorninger C, Spieck E, Wagner M, Daims H (2015) Nitrotoga-like bacteria are previously unrecognized key nitrite oxidizers in full-scale wastewater treatment plants. ISME J 9:708-720. https://doi.org/10.1038/ismej.2014.158

Lücker S, Wagner M, Maixner F, Pelletier E, Koch H, Vacherie B, Rattei T, Damsté JSS, Spieck E, Le Paslier D, Daims H (2010) A Nitrospira metagenome illuminates the physiology and evolution of globally important nitrite-oxidizing bacteria. Proc Natl Acad Sci U S A 107:13479-13484. https://doi.org/10.1073/pnas. 1003860107

Ma B, Yang L, Wang Q, Yuan Z, Wang Y, Peng Y (2017) Inactivation and adaptation of ammonia-oxidizing bacteria and nitriteoxidizing bacteria when exposed to free nitrous acid. Bioresour Technol 245:1266-1270. https://doi.org/10.1016/j.biortech.2017. 08.074

Maestre JP, Rovira R, Gamisans X, Kinney KA, Kirisits MJ, Lafuente J, Gabriel D (2009) Characterization of the bacterial community in a biotrickling filter treating high loads of $\mathrm{H}_{2} \mathrm{~S}$ by molecular biology tools. Water Sci Technol 59:1331-1337. https://doi.org/ 10.2166/wst.2009.111

Maixner F, Noguera DR, Anneser B, Stoecker K, Wegl G, Wagner M, Daims H (2006) Nitrite concentration influences the population structure of Nitrospira-like bacteria. Environ Microbiol 8:1487-1495

McKenzie N, Yue S, Liu X, Ramsay BA, Ramsay JA (2014) Biodegradation of naphthenic acids in oils sands process waters in an immobilized soil/sediment bioreactor. Chemosphere 109:164172. https://doi.org/10.1016/j.chemosphere.2014.02.001

Meincke M, Bock E, Kastrau D, Kroneck PMH (1992) Nitrite oxidoreductase from Nitrobacter hamburgensis: redox centers and their catalytic role. Arch Microbiol 158:127-131

Miłobędzka A, Muszyński A (2017) Can DNA sequencing show differences between microbial communities in Polish and Danish wastewater treatment plants? Water Sci Technol 75:1447-1454. https://doi.org/10.2166/wst.2017.015

Moussa MS, Sumanasekera DU, Ibrahim SH, Lubberding HJ, Hooijmans CM, Gijzen HJ, van Loosdrecht MCM (2006) Long term effects of salt on activity, population structure and floc characteristics in enriched bacterial cultures of nitrifiers. Water Res 40:1377-1388. https://doi.org/10.1016/j.watres.2006.01.029

Moyer CL, Eric Collins R, Morita RY (2017) Psychrophiles and psychrotrophs. Reference Module in Life Sciences, Elsevier. https:// doi.org/10.1016/B978-0-12-809633-8.02282-2

Mueller AJ, Jung M-Y, Strachan CR, Herbold CW, Kirkegaard RH, Wagner M, Daims H (2021) Genomic and kinetic analysis of novel Nitrospinae enriched by cell sorting. ISME J 15:732-745. https://doi.org/10.1038/s41396-020-00809-6 
Naruse T, Ban Y, Yoshida T, Kato T, Namikawa M, Takahashi T, Nishida M, Asakawa S, Watanabe T (2019) Community structure of microaerophilic iron-oxidizing bacteria in Japanese paddy field soils. Soil Sci Plant Nutr 65:460-470. https://doi.org/10. 1080/00380768.2019.1671139

Navada S, Vadstein O, Tveten A-K, Verstege GC, Terjesen BF, Mota VC, Venkataraman V, Gaumet F, Mikkelsen $\varnothing$, Kamstra A (2019) Influence of rate of salinity increase on nitrifying biofilms. J Clean Prod 238:117835. https://doi.org/10.1016/j.jclep ro.2019.117835

Navada S, Sebastianpillai M, Kolarevic J, Fossmark RO, Tveten A-K, Gaumet F, Mikkelsen Ø, Vadstein O (2020a) A salty start: brackish water start-up as a microbial management strategy for nitrifying bioreactors with variable salinity. Sci Total Environ 739:139934. https://doi.org/10.1016/j.scitotenv.2020.139934

Navada S, Vadstein O, Gaumet F, Tveten A-K, Spanu C, Mikkelsen Ø, Kolarevic J (2020b) Biofilms remember: osmotic stress priming as a microbial management strategy for improving salinity acclimation in nitrifying biofilms. Water Res 176:115732. https://doi. org/10.1016/j.watres.2020.115732

Nowka B, Daims H, Spieck E (2015a) Comparison of oxidation kinetics of nitrite-oxidizing bacteria: nitrite availability as a key factor in niche differentiation. Appl Environ Microbiol 81:745-753. https://doi.org/10.1128/AEM.02734-14

Nowka B, Off S, Daims H, Spieck E (2015b) Improved isolation strategies allowed the phenotypic differentiation of two Nitrospira strains from widespread phylogenetic lineages. FEMS Microbiol Ecol 91. https://doi.org/10.1093/femsec/fiu031

Numberger D, Ganzert L, Zoccarato L, Mühldorfer K, Sauer S, Grossart H-P, Greenwood AD (2019) Characterization of bacterial communities in wastewater with enhanced taxonomic resolution by full-length 16S rRNA sequencing. Sci Rep 9:9673. https://doi. org/10.1038/s41598-019-46015-z

Off S, Alawi M, Spieck E (2010) Enrichment and physiological characterization of a novel Nitrospira-like bacterium obtained from a marine sponge. Appl Environ Microbiol 76:4640-4646. https:// doi.org/10.1128/AEM.00320-10

Oren A, Garrity G, Parker C, Chuvochina M, Trujillo M (2020) Lists of names of prokaryotic Candidatus taxa. Int J Syst Evol Microbiol 70. https://doi.org/10.1099/ijsem.0.003789

Pande S, Kost C (2017) Bacterial unculturability and the formation of intercellular metabolic networks. Trends Microbiol 25:349-361. https://doi.org/10.1016/j.tim.2017.02.015

Palomo A, Pedersen AG, Fowler SJ, Dechesne A, Sicheritz-Pontén T, Smets BF (2018) Comparative genomics sheds light on niche differentiation and the evolutionary history of comammox Nitrospira. ISME J 12:1779-1793. https://doi.org/10.1038/ s41396-018-0083-3

Paver SF, Newton RJ, Coleman ML (2020) Microbial communities of the Laurentian Great Lakes reflect connectivity and local biogeochemistry. Environ Microbiol 22:433-446. https://doi.org/10. 1111/1462-2920.14862

Pester M, Maixner F, Berry D, Rattei T, Koch H, Lücker S, Nowka B, Richter A, Spieck E, Lebedeva E, Loy A, Wagner M, Daims H (2014) NxrB encoding the beta subunit of nitrite oxidoreductase as functional and phylogenetic marker for nitrite-oxidizing Nitrospira. Environ Microbiol 16:3055-3071. https://doi.org/10. 1111/1462-2920.12300

Petrovski S, Rice DTF, Batinovic S, Nittami T, Seviour RJ (2020) The community compositions of three nitrogen removal wastewater treatment plants of different configurations in Victoria, Australia, over a 12-month operational period. Appl Microbiol Biotechnol 104:9839-9852. https://doi.org/10.1007/s00253-020-10901-8

Piculell M, Suarez C, Li C, Christensson M, Persson F, Wagner M, Hermansson M, Jönsson K, Welander T (2016) The inhibitory effects of reject water on nitrifying populations grown at different biofilm thickness. Water Res 104:292-302. https://doi.org/10. 1016/j.watres.2016.08.027

Pradhan S, Srinivas TNR, Pindi PK, Kishore KH, Begum Z, Singh PK, Singh AK, Pratibha MS, Yasala AK, Reddy GSN, Shivaji S (2010) Bacterial biodiversity from Roopkund Glacier, Himalayan mountain ranges, India. Extremophiles 14:377-395. https://doi. org/10.1007/s00792-010-0318-3

Pulkkinen J (2020) Microbiology of biological filters in Recirculating Aquaculture Systems. Dissertation. University of Jyväskylä

Qian F, Huang Z, Liu Y, Grace OOW, Wang J, Shi G (2021) Conversion of full nitritation to partial nitritation/anammox in a continuous granular reactor for low-strength ammonium wastewater treatment at $20^{\circ} \mathrm{C}$. Biodegradation 32:87-98. https://doi.org/10. 1007/s10532-020-09923-w

Qiu G, Ting YP (2013) Osmotic membrane bioreactor for wastewater treatment and the effect of salt accumulation on system performance and microbial community dynamics. Bioresour Technol 150:287-297. https://doi.org/10.1016/j.biortech.2013.09.090

Ramos-Padrón E, Bordenave S, Lin S, Bhaskar IM, Dong X, Sensen CW, Fournier J, Voordouw G, Gieg LM (2011) Carbon and sulfur cycling by microbial communities in a gypsum-treated oil sands tailings pond. Environ Sci Technol 45:439-446. https:// doi.org/10.1021/es1028487

Reino C, van Loosdrecht MCM, Carrera J, Pérez J (2017) Effect of temperature on $\mathrm{N}_{2} \mathrm{O}$ emissions from a highly enriched nitrifying granular sludge performing partial nitritation of a low-strength wastewater. Chemosphere 185:336-343. https://doi.org/10. 1016/j.chemosphere.2017.07.017

Roden E, McBeth J, Blothe M, Percak-Dennett E, Fleming E, Holyoke R, Luther G, Emerson D (2012) The microbial ferrous wheel in a neutral $\mathrm{pH}$ groundwater seep. Front Microbiol 3:172

Sanders T, Fiencke C, Hüpeden J, Pfeiffer EM, Spieck E (2019) Cold Adapted Nitrosospira sp.: a potential crucial contributor of ammonia oxidation in cryosols of permafrost-affected landscapes in Northeast Siberia. Microorganisms 7:699. https://doi.org/10. 3390/microorganisms7120699

Santillan E, Phua WX, Constancias F, Wuertz S (2020) Sustained organic loading disturbance favors nitrite accumulation in bioreactors with variable resistance, recovery and resilience of nitrification and nitrifiers. Sci Rep 10:21388. https://doi.org/10.1038/ s41598-020-78314-1

Saunders AM, Albertsen M, Vollertsen J, Nielsen PH (2016) The activated sludge ecosystem contains a core community of abundant organisms. ISME J 10:11-20. https://doi.org/10.1038/ismej. 2015.117

Schmidt SK, Nemergut DR, Miller AE, Freeman KR, King AJ, Seimon A (2009) Microbial activity and diversity during extreme freezethaw cycles in periglacial soils, 5400 m elevation, Cordillera Vilcanota, Perú. Extremophiles 13:807-816. https://doi.org/10. 1007/s00792-009-0268-9

Sekine M, Akizuki S, Kishi M, Kurosawa N, Toda T (2020) Simultaneous biological nitrification and desulfurization treatment of ammonium and sulfide-rich wastewater: Effectiveness of a sequential batch operation. Chemosphere 244:125381. https:// doi.org/10.1016/j.chemosphere.2019.125381

Segawa T, Takeuchi N, Mori H, Rathnayake RMLD, Li Z, Akiyoshi A, Satoh H, Ishii S (2020) Redox stratification within cryoconite granules influences the nitrogen cycle on glaciers. FEMS Microbiol Ecol 96:fiaa199. https://doi.org/10.1093/femsec/fiaa199

Seuntjens D, Van Tendeloo M, Chatzigiannidou I, Carvajal-Arroyo JM, Vandendriessche S, Vlaeminck SE, Boon N (2018) Synergistic exposure of return-sludge to anaerobic starvation, sulfide, and free ammonia to suppress nitrite oxidizing bacteria. Environ Sci Technol 52:8725-8732. https://doi.org/10.1021/acs.est.7b06591

Skoyles A, Chaganti SR, Mundle SOC, Weisener CG (2020) Nitrification kinetics and microbial community dynamics of attached 
biofilm in wastewater treatment. Water Sci Technol 81:891-905. https://doi.org/10.2166/wst.2020.170

Song H-L, Lu Y-X, Yang X-L, Xu H, Singh RP, Du K-X, Yang Y-L (2020) Degradation of sulfamethoxazole in low-C/N ratio wastewater by a novel membrane bioelectrochemical reactor. Bioresour Technol 305:123029. https://doi.org/10.1016/j.biortech. 2020.123029

Sorokin DY, Lücker S, Vejmelkova D, Kostrikina NA, Kleerebezem R, Rijpstra WIC, Sinninghe Damsté JS, Le Paslier D, Muyzer G, Wagner M, Van Loosdrecht MCM, Daims H (2012) Nitrification expanded: discovery, physiology and genomics of a nitrite-oxidizing bacterium from the phylum Chloroflexi. ISME J. https:// doi.org/10.1038/ismej.2012.70

Spieck E, Ehrich S, Aamand J, Bock E (1998) Isolation and immunocytochemical location of the nitrite-oxidizing system in Nitrospira moscoviensis. Arch Microbiol 169:225-230. https://doi.org/10. 1007/s002030050565

Spieck E, Hartwig C, McCormack I, Maixner F, Wagner M, Lipski A, Daims H (2006) Selective enrichment and molecular characterization of a previously uncultured Nitrospira-like bacterium from activated sludge. Env Microbiol 8:405-415

Spieck E, Sass K, Keuter S, Hirschmann S, Spohn M, Indenbirken D, Kop LFM, Lücker S, Giaveno A (2020a) Defining culture conditions for the hidden nitrite-oxidizing bacterium Nitrolancea. Front Microbiol 11:1522. https://doi.org/10.3389/fmicb. 2020.01522

Spieck E, Spohn M, Wendt K, Bock E, Shively J, Frank J, Indenbirken D, Alawi M, Lücker S, Hüpeden J (2020b) Extremophilic nitriteoxidizing Chloroflexi from Yellowstone hot springs. ISME J 14:364-379. https://doi.org/10.1038/s41396-019-0530-9

Starkenburg SR, Larimer FW, Stein LY, Klotz MG, Chain PSG, Sayavedra-Soto LA, Poret-Peterson AT, Gentry ME, Arp DJ, Ward B, Bottomley PJ (2008) Complete genome sequence of Nitrobacter hamburgensis X14 and comparative genomic analysis of species within the genus Nitrobacter. Appl Environ Microbiol 74:2852-2863. https://doi.org/10.1128/AEM.02311-07

Steinmüller W, Bock E (1976) Growth of Nitrobacter in the presence of organic matter. Arch Microbiol 108:299-304. https://doi.org/ $10.1007 / \mathrm{bf00454856}$

Suarez C, Piculell M, Modin O, Langenheder S, Persson F, Hermansson M (2019) Thickness determines microbial community structure and function in nitrifying biofilms via deterministic assembly. Sci Rep 9:5110. https://doi.org/10.1038/s41598-019-41542-1

Tian W, Xiang X, Ma L, Evers S, Wang R, Qiu X, Wang H (2020) Rare species shift the structure of bacterial communities across sphagnum compartments in a subalpine peatland. Front Microbiol 10:3138. https://doi.org/10.3389/fmicb.2019.03138

Toplak N, Koren S, Jeršek M, Kovač M, Kokalj M, Golež M, Zarnik B, Jeršek B (2021) Diversity of bacterial populations with iron oxide/hydroxide formations in the abandoned Sitarjevec mine (Slovenia). Geomicrobiol J 38:164-173. https://doi.org/10.1080/ 01490451.2020.1822470

Ushiki N, Jinno M, Fujitani H, Suenaga T, Terada A, Tsuneda S (2017) Nitrite oxidation kinetics of two Nitrospira strains: the quest for competition and ecological niche differentiation. J Biosci Bioeng 123:581-589. https://doi.org/10.1016/j.jbiosc.2016.12.016

Ushiki N, Fujitani H, Aoi Y, Tsuneda S (2013) Isolation of Nitrospira belonging to sublineage II from a wastewater treatment plant. Microbes Environ 28:346-353. https://doi.org/10.1264/jsme2. me13042

Van Gool AP, Tobback PP, Fischer I (1971) Autotrophic growth and synthesis of reserve polymers in Nitrobacter winogradskyi. Arch Mikrobiol 76:252-264. https://doi.org/10.1007/BF00409120

Van Kessel MAHJ, Speth DR, Albertsen M, Nielsen PH, Op Den Camp HJM, Kartal B, Jetten MSM, Lücker S (2015) Complete nitrification by a single microorganism. Nature 528:555-559. https://doi.org/10.1038/nature16459

Vekeman B, Hoefman S, De Vos P, Spieck E, Heylen K (2013) A generally applicable cryopreservation method for nitrite-oxidizing bacteria. Syst Appl Microbiol 36:579-584. https://doi.org/10. 1016/j.syapm.2013.07.002

Vieira A, Galinha CF, Oehmen A, Carvalho G (2019) The link between nitrous oxide emissions, microbial community profile and function from three full-scale WWTPs. Sci Total Environ 651:2460 2472. https://doi.org/10.1016/j.scitotenv.2018.10.132

Waak MB, Hozalski RM, Hallé C, LaPara TM (2019) Comparison of the microbiomes of two drinking water distribution systemswith and without residual chloramine disinfection. Microbiome 7:87. https://doi.org/10.1186/s40168-019-0707-5

Wang D, Wang Q, Laloo A, Xu Y, Bond PL, Yuan Z (2016) Achieving stable nitritation for mainstream deammonification by combining free nitrous acid-based sludge treatment and oxygen limitation. Sci Rep 6:1-10. https://doi.org/10.1038/srep25547

Wang Z, Zheng M, Hu Z, Duan H, De Clippeleir H, Al-Omari A, Hu S, Yuan Z (2021) Unravelling adaptation of nitrite-oxidizing bacteria in mainstream PN/A process: Mechanisms and counter-strategies. Water Res 200:117239. https://doi.org/10.1016/j. watres.2021.117239

Wagner D, Spieck E, Bock E, Pfeiffer E-M (2001) Microbial life in terrestrial permafrost: Methanogenesis and nitrification in gelisols as potentials for exobiological processes. In: Horneck G, Baumstark-Khan C (eds) Astrobiologie-the quest for the conditions of life. Springer-Verlag, Berlin, pp 143-159

Wegen S (2017) Characterization of Candidatus Nitrotoga and its competitiveness in co-culture with Nitrospira. Dissertation. University of Hamburg

Wegen S, Nowka B, Spieck E (2019) Low temperature and neutral pH define "Candidatus Nitrotoga sp". as a competitive nitrite oxidizer in coculture with Nitrospira defluvii. Appl Environ Microbiol 85:e01186-e1218

White CP, DeBry RW, Lytle DA (2012) Microbial Survey of a fullscale, biologically active filter for treatment of drinking water. Appl Environ Microbiol 78:6390-6394. https://doi.org/10.1128/ AEM.00308-12

Winkler MKH, Boets P, Hahne B, Goethals P, Volcke EIP (2017) Effect of the dilution rate on microbial competition: R-strategist can win over kstrategist at low substrate concentration. PLoS ONE 12:1-12. https://doi.org/10.1371/journal.pone.0172785

Wu L, Ning D, Zhang B, Li Y, Zhang P, Shan X, Zhang Q, Brown M, Li Z, Van Nostrand JD, Ling F, Xiao N, Zhang Y, Vierheilig J, Wells GF, Yang Y, Deng Y, Tu Q, Wang A, Global Water Microbiome Consortium, Zhang T, He Z, Keller J, Nielsen PH, Alvarez PJJ, Criddle CS, Wagner M, Tiedje JM, He Q, Curtis TP, Stahl DA, Alvarez-Cohen L, Rittmann BE, Wen X, Zhou J (2019) Global diversity and biogeography of bacterial communities in wastewater treatment plants. Nat Microbiol 4:1183-1195. https:// doi.org/10.1038/s41564-019-0426-5

Xing W, Li J, Li D, Hu J, Deng S, Cui Y, Yao H (2018) Stable-isotope probing reveals the activity and function of autotrophic and heterotrophic denitrifiers in nitrate removal from organic-limited wastewater. Environ Sci Technol 52:7867-7875. https://doi.org/ 10.1021/acs.est.8b01993

Yang J, Chen S, Li H (2018) Dewatering sewage sludge by a combination of hydrogen peroxide, jute fiber wastes and cationic polyacrylamide. Int Biodeterior Biodegrad 128:78-84. https://doi. org/10.1016/j.ibiod.2016.10.027

Yang JP, Zhang J, Tian Q, Zhu YB, Li F, Wolfgang S (2019) Effect of intracellular carbon source (PHA) storage on the mixed growth microbial community resistance to low temperature. Huan Jing Ke Xue 40:1914-1921. https://doi.org/10.13227/j.hjkx.20180 9145 (Chinese) 
Yi X, Yi K, Fang K, Gao H, Dai W, Cao L (2019) Microbial community structures and important associations between soil nutrients and the responses of specific taxa to rice-frog cultivation. Front Microbiol 10:1-12. https://doi.org/10.3389/fmicb.2019.01752

Yu L, Li R, Mo P, Fang Y, Li Z, Peng D (2021) Stable partial nitrification at low temperature via selective inactivation of enzymes by intermittent thermal treatment of thickened sludge. Chem Eng J 418:129471. https://doi.org/10.1016/j.cej.2021.129471

Zeman NR, Irianni Renno M, Olson MR, Wilson LP, Sale TC, De Long SK (2014) Temperature impacts on anaerobic biotransformation of LNAPL and concurrent shifts in microbial community structure. Biodegradation 25:569-585. https://doi.org/10.1007/ s10532-014-9682-5

Zhang Y, Sun R, Zhou A, Zhang J, Luan Y, Jia J, Yue X, Zhang J (2018) Microbial community response reveals underlying mechanism of industrial-scale manganese sand biofilters used for the simultaneous removal of iron, manganese and ammonia from groundwater. AMB Express 8. https://doi.org/10.1186/ s13568-017-0534-7

Zhao W, Vermace RR, Mattes TE, Just C (2020) Impacts of ammonia loading and biofilm age on the prevalence of nitrogen-cycling microorganisms in a full-scale submerged attached-growth reactor. Water Environ Res. https://doi.org/10.1002/wer.1471

Zheng X, Lu D, Wang M, Chen W, Zhou G, Zhang Y (2018) Effect of chromium (VI) on the multiple nitrogen removal pathways and microbial community of aerobic granular sludge. Environ Technol 39:1682-1696. https://doi.org/10.1080/09593330.2017. 1337230

Zheng M, Li S, Ni G, Xia J, Hu S, Yuan Z, Liu Y, Huang X (2020) Critical factors facilitating Candidatus Nitrotoga to be prevalent nitrite-oxidizing bacteria in activated sludge. Environ Sci Technol 54:15414-15423. https://doi.org/10.1021/acs.est.0c04192

Zhou Y, Oehmen A, Lim M, Vadivelu V, Ng WJ (2011) The role of nitrite and free nitrous acid (FNA) in wastewater treatment plants. Water Res 45:4672-4682. https://doi.org/10.1016/j. watres.2011.06.025

Publisher's note Springer Nature remains neutral with regard to jurisdictional claims in published maps and institutional affiliations. 